\title{
The influence of contrasting values on consumer receptiveness to ethical information and ethical choices
}

\begin{abstract}
Ethical consumption is more likely when consumers are receptive to ethical product information and consider such information when making purchasing decisions. Building on communication theory, we develop and test a framework illustrating how different consumer values induce contrasting effects on consumers' willingness to choose ethical products through affecting consumer receptiveness to ethical product information.

We present an online survey with 590 US consumers, which was analyzed with covariancebased structural equation modeling (CB-SEM). Results show that altruistic and biospheric consumer values increase consumers' willingness to choose ethical products via trust in ethical advertising and ethical purchase decision involvement. In contrast, egoistic consumer values reduce ethical purchase decision involvement, and ultimately consumers' willingness to choose ethical products. Thus, we illustrate the mechanisms through which contrasting values take effect. Results are discussed in light of theoretical and managerial implications and reemphasize the need for better adaptation of ethical marketing to individual consumer characteristics.
\end{abstract}

\section{Keywords}

Ethical consumption, ethical advertising, consumer values, advertising trust, purchase decision involvement, sustainability marketing 


\section{THE INFLUENCE OF CONTRASTING VALUES ON CONSUMER RECEPTIVENESS TO ETHICAL INFORMATION AND ETHICAL CHOICES}

\section{Introduction}

In recent years, ethical consumption has become an important aspect of marketing research and business strategy, since society is increasingly aware of the problems associated with current consumption habits (Papadas, Avlonitis and Carrigan, 2017). Ethical consumption refers to the inclusion of environmental (e.g., environmental protection, animal welfare) and societal (e.g., responsible working conditions, fair trade) considerations in an individual's purchase decision (Pelsmacker, Driesen and Rayp, 2005). Consequently, ethical marketing focuses on the promotion of products and services with environmentally-friendly (e.g., organic produce, sustainable harvesting) and socially-responsible features (e.g., fair trade, no child labor) (Hasanzade, Osburg and Toporowski, 2018; Pelsmacker et al., 2005). Although many consumers are aware of the ethical implications of conventional consumption practices, and businesses are increasingly spending more on ethical advertising, ethical consumption is not growing accordingly (e.g., Doorn and Verhoef, 2015; Gleim et al., 2013; Pelsmacker and Janssens, 2007). This observation is known as the 'ethical purchasing gap', meaning that consumers often do not make ethical choices despite their declared ethical concerns. The literature discusses different reasons underlying this gap including methodological issues, situational influences and individual characteristics (e.g., Carrington, Zwick and Neville, 2016; Wei et al., 2017). Individual characteristics can be particularly relevant in helping to understand this gap because they may indicate if, and how, individuals direct their attention to ethical product information in the purchasing decision process (Hasanzade et al., 2018; Osburg et al., 2017).

Individual characteristics may be associated with consumers receptivity to ethical product 
information, and therefore foster ethical choices. Vested interest theory (VIT) (Crano, 1983; Crano and Prislin, 1995) suggests that an individual's interest in a product and its features is rooted in its compatibility with his/her value orientation, which is an essential individual characteristic. Vested interest can be seen as being manifested in involvement and trust (Crano, 1983; de Dominicis et al., 2014; Johnson and Eagly, 1989). Further, VIT indicates that both involvement and trust mediate the influence of values on behavior. The assumptions of VIT are in line with recent claims about the importance of providing decision-relevant ethical information to consumers, i.e., disclosing ethical features, which they actually consider when making a purchase decision (e.g., Hasanzade et al., 2018; Osburg et al., 2017). The direct influences of individual characteristics on ethical consumption, and indirect effects via constructs such as ascribed responsibility or self-determination have been studied widely (e.g., Groot and Steg, 2010; Han et al., 2017; Kiatkawsin and Han, 2017; Steg et al., 2005). However, to the best of our knowledge, their influence on consumer receptiveness to ethical product information has not yet been considered. We therefore contribute to the literature by emphasizing the importance of considering consumer's receptiveness to ethical product information, as opposed to identifying the best ways of presenting ethical product information, which is the prominent approach within extant literature. Moreover, we add to the growing body of research on VIT by testing whether the theory can be used as a foundation for research on ethical consumption, which is so far predominantly applied in general communication studies (e.g., Crano and Prislin, 1995; de Dominicis et al., 2014; Marks and Miller, 1987). Thus, this paper introduces and tests a conceptual model which shows how consumer receptiveness to ethical product information (specifically, ethical purchase decision involvement and trust in ethical advertising) mediates the influence of consumer values on ethical choices.

Also in line with the assumptions of VIT, previous research has shown that values are an 
important individual characteristic to be considered in the ethical purchasing context (e.g., Cho et al., 2013; Doorn and Verhoef, 2015; Goncalves, Lourenco and Silva, 2016; Groot and Steg, 2009; Urien and Kilbourne, 2011), not least because they represent fundamental guiding principles which determine behavior across situations (Groot and Steg, 2010; Jansson, Marell and Nordlund, 2010). Nevertheless, different value orientations might exert contrasting effects on ethical consumption. For example, values that reflect a strong tendency toward seeking individual benefits (e.g., egoistic values) are less likely to lead to ethical choices than value orientations which reflect societal and environmental considerations (e.g., altruistic and biospheric values) (Groot and Steg, 2010; Jansson et al., 2010). The results of previous studies suggest that some value orientations may foster ethical consumption (e.g., Groot and Steg, 2009; Han et al., 2017; Klöckner, 2013) whereas other value orientations may reduce ethical choices (e.g., Nordlund and Garvill, 2002; Steg et al., 2005). However, the evidence for this relationship is inconclusive as the latter could be shown in some cases (e.g., Doorn and Verhoef, 2015; Groot and Steg, 2010; Nordlund and Garvill, 2002; Steg et al., 2005), whereas others could not establish such a relationship (e.g., Han et al., 2017; Kiatkawsin and Han, 2017; Schuitema and Groot, 2015; Urien and Kilbourne, 2011). Hence, we empirically test to what extent different value orientations induce contrasting effects on consumers' willingness to choose ethical products.

To this end, we conduct an online study examining how consumer values affect consumers' willingness to choose ethical products through their receptiveness to ethical product information; the latter is represented by ethical purchase decision involvement and trust in ethical advertising. Findings illustrate a positive effect of consumer altruistic and biospheric values on consumers' willingness to choose ethical products, whilst a negative effect occurs for consumer egoistic values. Further, ethical purchase decision involvement and trust in ethical advertising are established as mediators for the relationships of consumer values on 
consumers' willingness to choose ethical products.

\section{Theoretical Development}

\subsection{Consumer's Receptiveness to Ethical Product Information}

Vested interest theory (VIT) (Crano, 1983; Crano and Prislin, 1995) helps us to understand what shapes consumers' receptiveness to ethical product information. This communication theory emphasizes that vested interest (or self-interest) summarizes an individual's perception of an object (e.g., a product), as both interesting and hedonically relevant. Vested interest is related to attitude-behavior consistency (Crano and Prislin, 1995). Consequently, the degree of vested interest ultimately influences individual behavior towards the object under consideration (Crano, 1983).

An important indicator of vested interest is an individual's involvement with the object and its characteristics (Crano and Prislin, 1995). In their meta-analysis, Johnson and Eagly (1989) distinguish three forms of involvement, which can activate an individual's self-concept, ultimately resulting in a behavioral response: value-relevant (i.e., supporting an individual's values), impression-relevant (i.e., maintaining the impression an individual makes on others), and outcome-relevant involvement (i.e., ensuring the realization of an individual's preferred consequences/goals). For the context of ethical consumption, value-relevant involvement becomes essential since it describes the extent to which an object reflects an individual's core values; i.e., ethical values, which have consistently been shown as important determinants of various forms of ethical behavior (e.g., Doorn and Verhoef, 2015; Groot and Steg, 2010; Kiatkawsin and Han, 2017; Urien and Kilbourne, 2011). Value-relevant involvement motivates individuals to act in line with their general beliefs (Johnson and Eagly, 1989). In other words, individuals should be particularly involved in purchase decisions which are in line with their value orientation. Hence, when applying value-relevant involvement to a purchasing context, 
consumer values should determine an individual's involvement with a purchase decision. According to VIT, such involvement should result in a purchase decision, which is in line with the individual's value orientation.

Vested interest is not only related to involvement, it also affects the likelihood of overestimating that others agree with oneself and one's beliefs (de Dominicis et al., 2014). In other words, individuals are more trustworthy towards others in the case of vested interest. This false-consensus or assumed-consensus effect (Crano, 1983; de Dominicis et al., 2014; Marks and Miller, 1987) particularly applies to individuals who are heavily involved in the object and its characteristics. Hence, trust should be considered as another manifestation of vested interest in addition to value-relevant involvement, with both constructs shaping an individual's receptiveness towards value-related information.

\subsection{Consumer Values}

Values represent fundamental principles, which guide individual behavior across situations (Schwartz, 1992). Consequently et al. (2005) emphasize that values are important factors influencing the consumption context. Thus, values have often been considered in studies on ethical consumption (e.g., Doorn and Verhoef, 2015; Groot and Steg, 2010; Kiatkawsin and Han, 2017; Urien and Kilbourne, 2011). This is illustrated in Table 1, which gives an overview of selected research on values and ethical consumption.

Studies in the area of ethical consumption differ between values oriented on one's self, and values focusing on collective interests (Doorn and Verhoef, 2015). This leads to a differentiation of three value orientations as outlined in Steg et al. (2005): Egoistic values (reflection of an individual's self-interest), altruistic values (emphasis on the welfare of other human beings), and biospheric values (consideration of the environment) (Stern et al., 1993). Individuals hold all three values to a certain extent, but their specific composition ultimately 
guides individual behavior (Groot and Steg, 2009). As shown in Table 1, the effect of altruistic and biospheric values on ethical consumption is well-documented. However, some studies point to an influence of egoistic values (e.g., Doorn and Verhoef, 2015; Groot and Steg, 2010; Nordlund and Garvill, 2002; Steg et al., 2005), whereas others do not find evidence for them (e.g., Han et al., 2017; Kiatkawsin and Han, 2017; Schuitema and Groot, 2015; Urien and Kilbourne, 2011). Thus, we consider the potential influences of the different values from a VIT perspective for the context of ethical consumption. We thereby focus on the effect of different values on consumers' receptiveness to ethical information, which has not been closely examined yet.

Insert Table 1 about here

\subsubsection{Consumer Altruistic and Biospheric Values}

Altruistic and biospheric values should drive ethical consumption because ethical product choices include both social (e.g., fair trade products) and environmental considerations (e.g., organic products). Ethical purchasing may even encompass individual sacrifices (Groot and Steg, 2009; Steg et al., 2005), because there is often a surcharge implicit within fair-trade products to ensure acceptable living and working standards for producers and suppliers.

Consequently, previous studies have shown that both, altruistic and biospheric values positively influence ethical consumption (e.g., Groot and Steg 2009; Han et al., 2017; Kiatkawsin and Han, 2017; Klöckner, 2013). The impact of biospheric values on consumer choices has been particularly documented for purchase decisions involving environmental product features (e.g., Doorn and Verhoef, 2015; Schuitema and Groot, 2015; Steg et al., 2005), whereas altruistic values predict purchase decisions where consumers consider the impact on other people (e.g., Pelsmacker et al., 2005; Yoganathan et al., 2019). Furthermore, a high correlation between both values has been reported (Doorn and Verhoef, 2015). Hence, we 
jointly consider altruistic and biospheric values as their combination summarizes the full sphere of ethical decisions including social justice, helpfulness, equality, peace, environmental protection, pollution prevention and unity with the earth (Steg et al., 2005).

Following VIT, in addition to direct effects on ethical consumption, potential effects on vested interest manifestations should also be considered, i.e., trust and involvement, which capture an individual's receptiveness to ethical information. In the first instance, consumer values are likely to influence an individual's ethical decision-making process (Vermeir and Verbeke, 2006). For example, environmental consciousness is linked to environmental involvement (Vlosky, Ozanne and Fotenot, 1999), which is similar to ethical purchase decision involvement. Similarly, personal characteristics are known to be important antecedents of involvement (Zaichkowsky, 1986). Therefore, consumer altruistic and biospheric values should be linked to ethical purchase decision involvement. The literature also indicates that values are associated with product as well as advertising trust, and that environmentally-concerned consumers show high levels of trust (Gleim et al., 2013; Osburg, Strack and Toporowski, 2016). This is in line with the false-consensus/assumed-consensus effect (Crano, 1983; de Dominicis et al., 2014; Marks and Miller, 1987). Hence, altruistic and biospheric values are supposed to increase trust in ethical advertising. Finally, previous studies have shown that values with a focus on collective interests drive ethical consumption as opposed to values that only consider benefits to one's self (Klöckner, 2013; Urien and Kilbourne, 2011; Vermeir and Verbeke, 2006). For example, consumers tend to be unwilling to pay a surcharge for ethical products if their values are oriented toward personal benefits (Doorn and Verhoef, 2015; Pelsmacker et al., 2005).

H1: Consumer altruistic and biospheric values are positively associated with ethical purchase decision involvement $\left(\mathbf{H}_{\mathbf{1}}\right)$, trust in ethical advertising $\left(\mathbf{H}_{\mathbf{1 b}}\right)$ and willingness to choose ethical products $\left(\mathbf{H}_{1 \mathbf{c}}\right)$. 


\subsubsection{Consumer Egoistic Values}

In contrast to altruistic and biospheric values, egoistic values are characterized by an individual's attempt to gain authority, social power, wealth and influence (Steg et al., 2005), and are associated with maximizing a consumer's individual benefits (Doorn and Verhoef, 2015). These attributes appear to be incompatible with characteristics of ethical consumption, according to which consumers need to suppress egoistic efforts and make occasionally (shortterm) sacrifices (Groot and Steg, 2009; Steg et al., 2005). For example, fair trade purchases require that an individual is willing to pay inherent additional costs by restraining egoistic purchase decision criteria (e.g., cost reduction).

Consequently, values focusing on self-interests have generally been found to negatively affect awareness of ethical issues (Nordlund and Garvill, 2002; Steg et al., 2005). High egoistic values are also negatively related to the feeling of moral obligation (Nordlund and Garvill, 2002), and a decrease in self-determination and motivation towards pro-environmental behavior (Groot and Steg, 2010). Urien and Kilbourne (2011) indicate that egoistic values particularly affect ethical consumption decisions negatively when the behavioral implications for future generations are not salient. Ethical choices appear to be less likely when individual benefits are pertinent during the purchase decision process (Jansson et al., 2010). Consequently, if egoistic values are dominant, consumers should be less involved in making the right ethical choice. Additionally, consumers with high egoistic values are supposed to act in accordance with rational-choice theory (Stern et al., 1993), possibly resulting in more skeptical and questioning attitudes towards ethical information. Further, the bias of false-consensus (Crano, 1983; de Dominicis et al., 2014; Marks and Miller, 1987) should not appear when egoistic values are dominant. Hence, egoistic values are likely to reduce trust in ethical advertising.

Finally, egoistic values should directly influence ethical consumption. For example, it has been shown that strong egoistic values decrease the likelihood of organic product choices (Doorn 
and Verhoef, 2015). Egoistic values also reduce donation intentions and preferences for ecofriendly cars (Groot and Steg, 2010). Moreover, consumers who are willing to pay a surcharge for fair trade products are characterized by low levels of values focusing on personal gratification (Pelsmacker et al., 2005). Interestingly, though, the results of some studies have presented contradictory findings and highlighted that egoistic values do not have an effect (e.g., Kiatkawsin and Han, 2017; Schuitema and Groot, 2015; Urien and Kilbourne, 2011). Groot and Steg (2009) suggest that egoistic values may (even positively) affect ethical behavior if such behavior implies personal benefits (e.g., cost reduction as a consequence of energy savings). However, ethical products are rarely positioned as providing individual benefits; hence, egoistic values should induce negative influences in a typical ethical purchasing situation.

H2: Consumer egoistic values are negatively associated with ethical purchase decision involvement $\left(\mathbf{H}_{2 \mathbf{a}}\right)$, trust in ethical advertising $\left(\mathbf{H}_{\mathbf{2}} \mathbf{b}\right)$ and consumers' willingness to choose ethical products $\left(\mathbf{H}_{2 \mathbf{c}}\right)$.

\subsection{Trust in Ethical Advertising}

Some businesses take advantage of an ethical positioning and present themselves as more ethical than the business actually is. These greenwashing attempts lead to consumer confusion and affect consumer trust in ethical advertising generally, even where ethical information is provided by reliable businesses (Gleim et al., 2013). However, trust is essential because ethical product information is a credence attribute, i.e., an aspect consumers cannot verify during the overall consumption experience. Hence, ethical attributes have an even higher risk of consumer skepticism (Nuttavuthisit and Thøgersen, 2017). Skepticism or distrust in ethical claims and ethical advertising ultimately act as purchase barriers in that consumers become suspicious 
towards the product offering (Gleim et al., 2013; Nuttavuthisit and Thøgersen, 2017). Hence, if consumers trust ethical advertising, they should be more likely to choose ethical products. Trust should not only influence ethical consumption, but also be affected by consumer values as previously outlined. Thus, trust in ethical advertising may function as a mediator between consumer values and ethical consumption. This assumption is theoretically supported by VIT, according to which vested interest is accompanied by a false-consensus/assumed-consensus effect (Crano, 1983; de Dominicis et al., 2014; Marks and Miller, 1987). Consequently, the supposed positive relationship between altruistic and biospheric values and willingness to choose ethical products should be mediated through an increase in trust in ethical advertising. Similarly, egoistic values should lead to reduced levels in trust, which imply a lower likelihood of selecting ethical products.

VIT also suggests that trust is interrelated with involvement. This is further indicated by the Elaboration Likelihood Model (Petty and Cacioppo, 1986), according to which an increased attention towards the object, as facilitated through trust and interest, allows for deeper elaboration through the central route of information processing. The central route is characterized by high individual involvement; hence, trust may strengthen involvement. It is important that the presented information is perceived as convincing and trustworthy in order to attract highly-involved individuals (Atkinson and Rosenthal, 2014); i.e., credibility/trustworthiness of the information becomes more important than source credibility for individuals with high involvement. In line with this, skepticism towards fair trade information has been shown to affect product interest (Pelsmacker and Janssens, 2007). If advertising trust is low, consumers do not perceive the presented information to be worth processing and the probability of attitude change is reduced (Soh, Reid and King, 2009). In other words, if consumers mistrust ethical advertising, ethical product information is unlikely to be further considered in the purchase decision process. 
H3: Trust in ethical advertising is positively associated with ethical purchase decision involvement ( $\left.\mathbf{H}_{3 \mathbf{a}}\right)$ and consumers' willingness to choose ethical products $\left(\mathbf{H}_{3 \mathbf{b}}\right)$ and mediates the relationship between consumer altruistic and biospheric values and consumers' willingness to choose ethical products $\left(\mathbf{H}_{3 \mathbf{c}}\right)$ as well as consumer egoistic values and consumers' willingness to choose ethical products $\left(\mathbf{H}_{3 \mathbf{d}}\right)$.

\subsection{Ethical Purchase Decision Involvement}

Involvement 'indicates the amount of arousal, interest, or drive evoked by a particular stimulus or situation' (Mitchell, 1979, p. 194). In general, involvement has diverse forms, depending on its focus, for example, on advertising, the product, or purchasing process (Lin and Chen, 2006). Purchase decision involvement becomes important for ethical consumption. This form of involvement focuses on 'the extent to which a consumer cares about what she or he buys and, correspondingly, the extent to which he or she is motivated to make the right choice' (Mittal, 1989, p. 159). Thus, ethical purchase decision involvement is the extent to which consumers are concerned about considering ethical information when making a purchase decision.

For example, more ethical consumer choices can be observed if consumers care about the environment and making the right purchase decision (both are facets of ethical purchase decision involvement) (Vermeir and Verbeke, 2006; Wei et al., 2017). Further, consumers' willingness to pay for ethical products increases if consumers are involved in ethical information, which is again an important part of ethical purchase decision involvement (Vlosky et al., 1999). As VIT also supports an influence of involvement on behavior (Crano, 1983; Crano and Prislin, 1995), ethical purchase decision involvement is expected to affect consumers' ethical purchasing behavior.

Finally, the elaboration on VIT has shown that involvement may function as a mediator between consumer values and ethical choices. Involvement can be the crucial indicator of 
vested interest, bridging individual characteristics and behavior (Crano and Prislin, 1995). If the content of involvement matches with an individual's value orientation, a positive behavioral consequence is more likely (Johnson and Eagly, 1989). Thus, if values which focus on others and the environment are dominant, ethical purchase decision involvement should be higher, which ultimately facilitates ethical choices. Contrary to this, if egoistic values dominate, ethical choices should be negatively influenced through a reduced ethical purchase decision involvement.

H4: Ethical purchase decision involvement is positively associated with consumers' willingness to choose ethical products $\left(\mathbf{H}_{4} \mathbf{a}\right)$ and mediates the relationship between consumer altruistic and biospheric values and consumers' willingness to choose ethical products $\left(\mathbf{H}_{4 \mathbf{b}}\right)$ as well as consumer egoistic values and consumers' willingness to choose ethical products $\left(\mathbf{H}_{4 \mathbf{c}}\right)$.

Insert Figure 1 about here

Figure 1 visualizes our conceptual framework, which illustrates the contrasting effects of consumer values on ethical consumer choices, mediated through an individual's receptiveness to ethical product information.

\section{Methods}

To test the conceptual framework, an online survey of US citizens was conducted based on a probability sampling method, so as to ensure a demographically representative sample. Data was collected through an online panel provider (www.clickworker.com), which recruited US American consumers for participation in the survey. A total of 595 respondents completed the full survey, leaving 590 usable responses after the elimination of straightliners. The mean age was 36.93 years $(S D=13.23$, range from 18 to 74$)$ with $43.5 \%$ of the respondents being male and $56.5 \%$ female. Table 2 presents further information about the sample. 
Insert Table 2 about here

The constructs of the conceptual framework were operationalized with established scales: 1) Consumer Values (i.e. altruistic, biospheric and egoistic values) were assessed with 12 items originally introduced by Steg et al. (2005); 2) Trust in Ethical Advertising was measured with the six-item Advertising Trust scale from Gleim et al. (2013) and Soh et al. (2009), which was adapted to refer to two aspects of ethical consumption; and 3) Ethical Purchase Decision Involvement was assessed with an adapted version of the 4-item Purchase Decision Involvement scale from Mittal (1989). The Appendix documents all scales and items ${ }^{1}$. The mean values, standard deviations and correlation matrix are presented in Table 3 . Table 4 shows the scales' reliability, validity, construct reliability and average variance extracted.

Willingness to choose ethical products was measured according to the procedure detailed by Osburg et al. (2016). Respondents received 14 different descriptions of ethical products in a row, either belonging to durable goods, represented by chairs, or Fast-Moving Consumer Goods (FMCG), represented by chocolate bars. Each of the 14 product descriptions was compared to a conventional alternative (i.e., neither organic nor fair trade). Subsequently, respondents were asked to select either an ethical or conventional product by answering a question about which of the presented versions they would choose when shopping. A respondent's willingness to choose an ethical product was computed as an aggregate measure of his/her choices for these 14 ethical product descriptions (yes/no) in comparison to the conventional choice. Hence, the measure for willingness to choose ethical products is an average score, which combines an individual's response to the 14 choices.

$$
\text { Insert Tables 3, } 4 \text { and } 5 \text { about here }
$$

\footnotetext{
${ }^{1}$ The survey focused on organic and fair trade purchases because pro-environmental and fairly traded products are the most typical examples of ethical consumer choices (Shaw et al., 2005).
} 
Discriminant validity was assessed using two methods. First, the correlation between the constructs was less than 0.85 (Kline, 2011), ranging between 0.01 and 0.54 , as shown in Table 3. Second, as listed in Table 5, the square of the correlation $\left(\phi^{2}\right)$ for each pair of underlying constructs was less than the average variance explained (AVE) (Chiang, Kocabasoglu-Hillmer and Suresh, 2012; Fornell and Larcker, 1981; Sekaran, 2000). We also performed various steps to minimize common method variance (CMV) bias. As advised by other methodologists (Tourangeau, Rips and Rasinski, 2000), we used familiar words and avoided double-barreled questions and technical words. This helped us to keep items simple, specific and concise for research participants. Additionally, the participants were informed about the anonymity of the study and only aggregate data were utilized. Statistically, Harman's one-factor test was applied to check CMV. The variance produced by the four-factor solution $(73.36 \%)$ was greater than a single factor solution or other combinations.

Table 6 presents item contents, exploratory factor analysis (EFA) and cross-loadings, uncovering the underlying structure of the involved variables forming different constructs. A four-factor solution with $73.36 \%$ of variance was obtained through Varimax rotation. All relative loadings were greater than 0.70 , except for one item $(\mathrm{CABV} 8=0.667)$. This was later deleted (due to high modification indices) when confirmatory factor analysis (CFA) was conducted. Thus, prior to CFA, the reliability and validity of the constructs were strongly supported. The cross-loadings in Table 5 can be observed to further perceive the validity of the constructs.

\section{Analysis and Results}

Several steps were performed to reach the final model presented in Figure 3. We first checked the relationship between consumers' altruistic and biospheric values (CABV), as shown in Figure $2 \mathrm{a}$, Figure $2 \mathrm{~b}$ and Figure $2 \mathrm{c}$. This step was undertaken based on the theoretical 
arguments that the two constructs are different but inter-related, as indicated in previous research (e.g., Groot and Steg, 2009, 2010; Han et al., 2017; Kiatkawsin and Han, 2017). Moreover, seminal work in this area demonstrates that biospheric and altruistic valueorientations are not sufficiently differentiated in a general sample (Stern and Dietz, 1994). We tested the models individually and then in combination to check the interrelationship. With a strong relationship, the fit indices are equally satisfactory for Figure 2a (separate models) and Figure 2c (a combined-two factor solution). However, the fit indices and loadings for a singlefactor solution were weak compared to a two-factor solution. Which supports our initial EFA exploration, which showed that the relative items load on a single factor. The detailed fit indices are provided underneath Figure 2a, Figure $2 \mathrm{~b}$ and Figure 2c.

Since, the main purpose is to test the structural paths and hypotheses, we utilized the combined model for further analysis. Subsequently, Table 7 was developed which presents a series of alternative models. Model 1 was initiated by regressing all independent variables -consumer altruistic and biospheric values (CABV), consumer egoistic values (CEV), ethical purchase decision involvement (EPDI), and trust in ethical advertising (TEA) - on the dependent variable, willingness to choose ethical products (WCEP). All variables were significantly associated with the dependent variable. Models 2 and 3 represent the moderating effects of involved products (chocolates and chairs). The detailed results (including fit indices) obtained from two models are reported in Table 7.

Following the procedure detailed by Byrne (2004), Byrne and Stewart (2006), and Dimitrov (2010), we also tested for configural, measurement, and structural invariance. In setting the baseline model to establish the configural invariance, the same number of factors and their item patterns were used; no quality constraints were imposed. We then set the constraints (both at measurement and structural levels) such as factor loadings, intercepts, and residual/covariances for the subsequent models to test their differences (Dimitrov, 2010). The $\chi^{2}$ difference tests 
showed that the two models (model 2 based on chocolate and model 3 based on chairs) were not statistically different, with $\Delta \chi^{2}=18.86$, d.f $=19$ and $p$-value $=0.466$ for measurement weights; $\Delta \chi^{2}=28.85$, d.f $=24$ and $p$-value $=0.226$ for structural weights; $\Delta \chi^{2}=34.71$, d.f $=$ 27 and $p$-value $=0.146$ for covariances and $\Delta \chi^{2}=34.91$, d.f $=29$ and $p$-value $=0.208$ for residuals. The model fit indices for the constrained models were as follows: $\chi^{2} / \mathrm{df} \leq 1.151$, GFI $\geq 0.94 ;$ AGFI $\geq 0.92 ;$ CFI $\geq 0.994 ;$ TLI $\geq 0.993 ;$ IFI $\geq 0.994 ;$ RFI $\geq 0.954 ;$ NFI $\geq 0.960$ RMSEA $\leq 0.17$. Thus, it was not necessary to conduct path-by-path analysis to check which specific estimates are different for each product category.

Insert Figure 2 and Table 7 about here

Figure 3 (final model) depicts the hypothesized links and the relevant standardized results. $\mathrm{H}_{1}$ shows the relationship of CABV with other variables through the sub-hypotheses. Hypothesis $\mathrm{H}_{1 \mathrm{a}}$ proposes that CABV positively affects EPDI. This hypothesis is supported at $p<0.01$ with $\beta=0.49$ and C.R $=9.920$. Hypotheses $\mathrm{H}_{1 \mathrm{~b}}(\mathrm{CABV}$ positively affects TEA $)$ and $\mathrm{H}_{1 \mathrm{c}}(\mathrm{CABV}$ positively affects WCEP) are also supported with $\beta=0.40(p<0.01, \mathrm{C} . \mathrm{R}=9.096)$ and $\beta=0.21$ $(p<0.01, \mathrm{C} . \mathrm{R}=3.963)$ respectively. Hypotheses $\mathrm{H}_{2 \mathrm{a}} \mathrm{H}_{2 \mathrm{~b}}$ and $\mathrm{H}_{2 \mathrm{c}}$ state that CEV negatively affects EPDI, TEA and WCEP respectively, of which two are supported at $\beta=-0.13(p<0.01$, C. $\mathrm{R}=-3.498$ for $\left.\mathrm{H}_{2 \mathrm{a}}\right)$, and $\beta=-0.08\left(p<0.1, \mathrm{C} . \mathrm{R}=1.924\right.$ for $\left.\mathrm{H}_{2 \mathrm{c}}\right)$, as indicated in Figure 3 . However, $\mathrm{H}_{2 \mathrm{~b}}$ is insignificant, $\beta=-0.05(\mathrm{C} . \mathrm{R}=-1.341$ at $p=0.18)$.

$\mathrm{H}_{3}$ states that TEA is positively associated with EPDI $\left(\mathrm{H}_{3 \mathrm{a}}\right)$ and WCEP $\left(\mathrm{H}_{3 \mathrm{~b}}\right)$ and both hypotheses are supported $(\beta=0.26, p<0.01, \mathrm{C} . \mathrm{R}=6.317$ and $\beta=0.22, p<0.01, \mathrm{C} . \mathrm{R}=5.053)$. Hypothesis $\mathrm{H}_{4 \mathrm{a}}$, which proposes that EPDI positively affects WCEP, is also supported with $\beta$ $=0.10$ and C.R $=1.788(p<0.1)$. Additionally, the fit indices with a non-significant $p$-value $(0.268)$ and $R^{2}$ values ranging from $17 \%$ to $45 \%$ for the final model are provided underneath Figure 3. The $p$-value exhibited stronger support for the model with better fit indices compared to alternative models. 


\section{Insert Figure 3 about here}

The mediation analyses were conducted by using bootstrapping as recommended by Preacher and Hayes (2008), with 5000 samples and 95\% confidence interval. The results are summarized in Figure 4 and Table 8. The first mediator, CABV (independent variable, IV) was significantly related to TEA (mediator, that is an indirect effect and is called path " $\mathrm{a}$ ") $[(\beta=0.37, \mathrm{t}=10.402$, $p<0.001)]$ and TEA was also significantly associated with WCEP, dependent variable (DV) $[(\beta=0.22, \mathrm{t}=6.523, p<0.001)$, that is referred to as path $\mathrm{b}]$. CABV was also significantly associated with WCEP $[(\beta=0.27, \mathrm{t}=8.985 p<0.001)]$, which is the direct effect of the independent variable to the dependent variable and is called path "c". When the full model was examined, the analysis indicated that the direct effect of CABV on WCEP was reduced to $\beta=$ $0.19(\mathrm{t}=5.972 p<0.001)$ from the original direct effect $[\beta=0.27(\mathrm{t}=8.985 p<0.001)$, this last path is referred as "c"”]. The results thus show a partial mediation with confidence intervals that ranged from 0.050 to 0.122 , as this path is still significant but reduced - depicting the fact that TEA partially mediates the relationship between CABV and WCEP $\left(\mathrm{H}_{3 c}\right)$. The second mediator, $\mathrm{H}_{3 \mathrm{~d}}$ states that TEA mediates the relationship between CEV (IV) and WCEP (DV). IV was significantly related to the mediator $[(\beta=-0.06, \mathrm{t}=-2.188, p<0.05)$, path a, indirect effect $]$. The mediator was also significantly associated with the DV, $[(\beta=0.29, \mathrm{t}=9.159 p<$ 0.001), path b]. The direct effect of the IV on the DV (path c) showed significant results with $\beta=-0.07, \mathrm{t}=-3.255$. The path $\left(\mathrm{c}^{\prime}\right)$ reduced to $\left.\beta=-0.05, \mathrm{t}=-2.340\right]$, showing a partial mediation with confidence intervals ranging from -0.037 to 0.001 .

\section{Insert Figure 4 and Table 8 about here}

Similarly, for the third mediator, the results from analyzing $\mathrm{H}_{4 \mathrm{~b}}$ revealed that CABV (IV) was significantly related to $\operatorname{EPDI}[(\beta=0.50, \mathrm{t}=15.430, p<0.001)$, path a]. The mediator (EPDI) was also significantly associated with $\mathrm{WCEP}(\mathrm{DV})[(\beta=0.17, \mathrm{t}=4.443 p<0.001)$, path $\mathrm{b}]$. The direct effect of the IV on the DV (path c) showed significant results with $\beta=0.27, \mathrm{t}=$ 
8.985 and $p<0.001$. However, in the full model, the path ( $\mathrm{c}^{\prime}$ ) reduced to $\beta=0.18, \mathrm{t}=5.315, p$ $<0.001)$ ], indicating the existence of a partial mediation with confidence intervals ranging from 0.050 to 0.126 . The final mediator $\mathrm{H}_{4 \mathrm{c}}$ states that EPDI mediates the relationship between $\mathrm{CEV}$ and WCEP. CEV was significantly associated with EPDI $(\beta=-0.13, \mathrm{t}=-4.188, p<0.001$, path a). EPDI was also significantly related to $\operatorname{WCEP}(\beta=0.26, \mathrm{t}=7.956 p<0.001$, path $\mathrm{b})$. The direct effect of CEV on WCEP showed significant results with $\beta=-0.07, \mathrm{t}=-3.255$ and $p<0.001$, path $\mathrm{c}$. In the full mediating model, the path showed insignificant results with $\beta=-$ $0.04, \mathrm{t}=-1.805, p<0.05$. This indicated a full mediation with confidence intervals ranging from -0.053 to -0.019 .

\section{Discussion and Conclusion}

As ethical consumption practices have not increased as much as consumers' expressed ethical concerns suggest (Doorn and Verhoef, 2015; Gleim et al., 2013), it becomes important to better understand the determinants of ethical choices. We focus on the literature gap in the area of consumers' receptiveness to ethical product information (e.g., Hasanzade et al., 2018; Osburg et al., 2017) as an important driver of ethical choices. Building on communication theory (VIT), we advance previous research by developing and testing a framework that specifies contrasting effects of different values on consumers' receptiveness to ethical information, and ultimately consumers' willingness to choose ethical products.

\subsection{Theoretical Contributions}

This research advances our understanding of how values influence ethical consumption by showing that contrasting effects may indeed occur. In line with previous research (e.g., Groot and Steg, 2009; Han et al., 2017; Klöckner, 2013), we demonstrate that consumer altruistic and biospheric values increase the willingness to choose ethical products $\left(\mathrm{H}_{1 \mathrm{c}}\right)$. We thereby also 
provide additional support for the theoretical argument that consumer altruistic and biospheric values are different but inter-related (e.g., Groot and Steg, 2009, 2010; Han et al., 2017; Kiatkawsin and Han, 2017), and specifically, that they are inter-related to an extent justifying that they do not have to be further differentiated in a general sample (Stern and Dietz, 1994). Moreover, whilst some studies point to negative influences of egoistic values (e.g., Doorn and Verhoef, 2015; Groot and Steg, 2010; Nordlund and Garvill, 2002; Steg et al., 2005), such effects were not significant in others (e.g., Han et al., 2017; Kiatkawsin and Han, 2017; Schuitema and Groot, 2015; Urien and Kilbourne, 2011), and the present research also contributes to this debate. Most of these previous studies have focused on selected aspects of ethical consumption (environmental or social impact); however, our research includes the simultaneous consideration of both facets. Thus, when organic and fair-trade product features are jointly presented, egoistic values negatively affect consumers' willingness to choose ethical products $\left(\mathrm{H}_{2 \mathrm{c}}\right)$.

Extensive research has explored how values not only influence behavioral decisions, but also affect consumers' awareness of behavioral consequences and feelings of responsibility (e.g., Han et al., 2017; Kiatkawsin and Han, 2017; Steg et al., 2005) as well as self-determination (Groot and Steg, 2010) and moral obligation (Nordlund and Garvill, 2002). Due to the focus on psychological variables, previous research has often underestimated the extent to which consumers may differ regarding their receptiveness to ethical product information (e.g., Hasanzade et al., 2018; Osburg et al., 2017), which can be represented by ethical purchase decision involvement and trust in ethical advertising. However, a better understanding of such receptiveness is important for both practitioners and researchers.

In the present study, we build on VIT, to advance the understanding of ethical marketing by showing that consumer values are the foundation for consumer receptiveness to ethical product information. Specifically, our findings confirm that consumer altruistic and biospheric values 
increase ethical purchase decision involvement $\left(\mathrm{H}_{1 \mathrm{a}}\right)$ and trust in ethical advertising $\left(\mathrm{H}_{1 \mathrm{~b}}\right)$, whereas consumer egoistic values are related to a reduced involvement in making the right ethical choice $\left(\mathrm{H}_{2 \mathrm{a}}\right)$. Interestingly, though, consumer egoistic values do not affect trust in ethical advertising (contrary to the predictions of $\mathrm{H}_{2 b}$ ). Whilst consumer egoistic values may lead to more rational consumption choices that are aligned with individual benefits (Stern et al., 1993), this does not mean that such consumers distrust ethical advertising per se, which is a promising finding.

Further, our study provides a deeper insight into the role of consumers' receptiveness to ethical information by showing that both ethical purchase decision involvement and trust in ethical advertising are related to positive outcomes. The positive influence of trust in ethical advertising on consumers' willingness to choose ethical products $\left(\mathrm{H}_{3 \mathrm{~b}}\right)$ matches with findings of a negative influence of distrust on ethical consumption (e.g., Gleim et al., 2013; Nuttavuthisit and Thøgersen, 2017). We find similar results for ethical purchase decision involvement $\left(\mathrm{H}_{4 a}\right)$ and therefore extend previous research, which focuses on sub-categories of ethical involvement such as environmental involvement (e.g., Vermeir and Verbeke, 2006; Wei et al., 2017). Additionally, we advance our understanding of the interrelationship between trust and involvement by establishing that trust in ethical advertising may increase ethical purchase decision involvement $\left(\mathrm{H}_{3 \mathrm{a}}\right)$, which again points to the importance of a trustworthy communication of ethical product features.

Based on these considerations and the line of thought of VIT (Crano, 1983; Crano and Prislin, 1995), we conclude by uncovering the causal chain, in which ethical purchase decision involvement and trust in ethical advertising mediate the relationship between consumer values and consumers' willingness to choose ethical products. Trust in ethical advertising partially mediates the relationship of consumer altruistic and biospheric $\left(\mathrm{H}_{3 c}\right)$ as well as consumer egoistic values $\left(\mathrm{H}_{3 \mathrm{~d}}\right)$ on consumers' willingness to choose ethical products, whilst ethical 
purchase decision involvement mediates the influence of altruistic and biospheric values $\left(\mathrm{H}_{4 \mathrm{~b}}\right)$ on willingness to choose ethical products partially, and fully for consumer egoistic values $\left(\mathrm{H}_{4 c}\right)$. Thus, we lay the groundwork for future research by indicating that different consumer values may induce contrasting effects on ethical consumer choices because different value orientations lead to contrasting effects on consumer's receptiveness to ethical product information, which ultimately determines behavioral decisions.

\subsection{Managerial Implications}

The present research indicates that marketing managers concerned with promoting ethical products should better understand the complex phenomenon that is consumers' receptiveness to ethical product information. Thus, they must recognize the importance of developing and implementing targeted marketing communications, which has been emphasized from a policy perspective (European Commission, 2012), as well as in the academic literature (Osburg et al., 2019; Yoganathan et al., 2019). Our research examined the underlying reasons at the individual consumer level and illustrates the key roles of different consumer values in shaping consumers' attitudes and choices in relation to ethical product marketing. Based on our results, we recommend that practitioners a) appreciate the contrasting effects of different consumer values that ultimately manifest in divergent consumption choices; and b) dedicate focus and resources to improving consumers' receptiveness to ethical product information and overall involvement in the purchase decision. Since our investigation considered both fast-moving and durable consumer goods, the findings have wide-ranging implications for ethical marketing, which we elaborate upon in the following sections.

Some consumers are not receptive to the most frequent or more traditional forms of ethical product advertising (i.e., product attributes such as "organic" and "fair trade"), which focus on environmental and societal implications in an attempt to influence consumer behavior. 
Positioning ethical products as environmentally-friendly and socially-beneficial goods may induce ethical choices for some consumers and lead to stronger purchase decision involvement and trust in ethical advertising. However, this does not hold true for all consumers. To be truly successful in the long run, practitioners must also target consumers who are motivated to consume ethically due to purely egoistic reasons, which requires different approaches than traditional forms of ethical advertising.

Our research indicates that practitioners should segment their market and identify groups of consumers based on their values - those who are interested in the welfare of others and the environment, as opposed to consumers who primarily follow their own interests. Such valuesbased segmentation approaches have previously been applied in sustainability-related marketing research; for example, in the marketing of hybrid vehicles (McLeay et al., 2018) and wood-polymer composite products (Osburg et al., 2016). The typical and traditional promotion of ethical products by emphasizing ethical features seems to be only of interest for the former consumer group, who can be treated as a homogeneous segment pursuing consumption patterns with benefits beyond themselves. In contrast, appealing to a consumer's social and environmental responsibility (or even a company's responsibility) does not seem to be attractive to all consumers and may even induce negative effects for consumers with strong egoistic values. For this consumer segment, it may be advantageous to emphasize the individual benefits of ethical purchasing, such as cost savings when buying energy-efficient household appliances (Ward et al., 2011) or health benefits associated with environmentally-friendly production (Osburg et al., 2017). Thus, understanding the core values of consumers is essential for marketers interested in actually increasing ethical consumption across the entire market. Additionally, if ethics is an important part of a product's (or company's) positioning, marketers need to work towards improving consumer's receptiveness to ethical information in order to increase its purchase relevance. Specifically, companies should present and emphasize ethical 
information items in a manner in which they better engage consumers based on their individual characteristics (e.g. consumer values). This can be done by increasing consumer involvement in ethical product choices by making ethical information easier for consumers to relate to and adapting it for specific segments (an ethical product is good for self vs. good for the planet), or through congruent audio-visual cues to enhance the experiential aspects (Osburg et al., 2017; 2019; Yoganathan et al., 2019).

In addition to involvement, marketers should also acknowledge the role of trust in ethical product advertising, because this may induce stronger consumer involvement in ethical purchase decisions, as well as having other behavioral implications such as loyalty. In this context, certification of ethical claims through independent third-parties may prove to be a successful measure to further stimulate ethical consumption as opposed to the presentation of self-declared ethical information (Bradu, Orquin and Thogersen, 2014).

\subsection{Limitations and Future Research}

The following limitations of our study should be considered, which offer avenues for future research. First, the proposed framework may encourage future studies to uncover moderators, which could weaken the negative influence of consumer egoistic values on ethical consumption via consumer's receptiveness to ethical product information. For example, negative effects may depend on the considered industry since some industries are associated with individual benefits of ethical consumption (e.g., energy savings in the electric cars industry). Second, this study measures consumers' willingness to choose ethical products for two product categories; durable goods and Fast-Moving Consumer Goods, to cover a broader range of ethical purchase decisions. As research has shown that ethical purchase decisions may also depend on certain product characteristics (Luchs et al., 2010), future studies should explore whether the influence of individual differences varies, subject to product features. Third, we operationalized ethical 
products as organic and fair-trade products; however, ethical product features can be more manifold (e.g., including animal welfare), so that these features deserve attention in future research. Finally, the present study was conducted with U.S. consumers, suggesting that future research should focus on a cross-cultural comparison (e.g., through an integration of Hofstede's Cultural Dimensions Theory) in order to address the generalizability of the obtained results for countries where ethical issues are more or less dominant in public discourse. 


\section{Appendix: Scales}

\begin{tabular}{|c|c|}
\hline Construct/Items & Source \\
\hline $\begin{array}{l}\text { Consumer Values }(0=\text { not at all important, } 7 \text { = the most important) } \\
\text { Please rate the importance of the following } 12 \text { values as guiding principles in your } \\
\text { life. } \\
\text { Authority: the right to lead or command (egoistic) } \\
\text { Social power: control over others, dominance (egoistic) } \\
\text { Wealth: material possessions, money (egoistic) } \\
\text { Influential: having an impact on people and events (egoistic) } \\
\text { Social justice: correcting injustice, care for the weak (altruistic) } \\
\text { Helpful: working for the welfare of others (altruistic) } \\
\text { Equality: equal opportunity for all (altruistic) } \\
\text { A world at peace: free of war and conflict (altruistic) } \\
\text { Protecting the environment: preserving nature (biospheric) } \\
\text { Preventing pollution (biospheric) } \\
\text { Respecting the earth: live in harmony with other species (biospheric) } \\
\text { Unity with nature: fitting into nature (biospheric) }\end{array}$ & Steg et al. (2005) \\
\hline $\begin{array}{l}\text { Trust in Ethical Advertising }(1=\text { strongly disagree, } 7=\text { strongly agree }) \\
\text { Information conveyed in advertisements for organic and fair-trade products is... } \\
\text { Honest } \\
\text { Truthful } \\
\text { Credible } \\
\text { Reliable } \\
\text { Accurate } \\
\text { Factual }\end{array}$ & $\begin{array}{l}\text { adapted from Gleim et } \\
\text { al. (2013) and Soh et al. } \\
\text { (2009) }\end{array}$ \\
\hline $\begin{array}{l}\text { Ethical Purchase Decision Involvement } \\
\text { In selecting from the many types and brands of this product available in the } \\
\text { market, would you say that: I would not care at all which one I buy (1) - I would } \\
\text { care a great deal which one I would buy ( } 7 \text { ) } \\
\text { Do you think that the various types and brands of this product available in the } \\
\text { market are all very alike or are all very different? They are alike (1) - They are } \\
\text { all very different (7) } \\
\text { How important would it be to you to make a right choice of this product? Not at } \\
\text { all important (1) - Extremely important (7) } \\
\text { In making your selection of this product, how concerned would you be about the } \\
\text { outcome of your choice? Not at all concerned (1) - Very much concerned (7) }\end{array}$ & Mittal (1989) \\
\hline
\end{tabular}




\section{References}

Atkinson, L., \& Rosenthal, S. (2014). Signaling the green sell: The influence of eco-label source, argument specificity, and product involvement on consumer trust. Journal of Advertising, 43(1), 33-45.

Bradu, C., Orquin, J. L., \& Thogersen, J. (2014). The mediated influence of a traceability label on consumer's willingness to buy the labelled product. Journal of Business Ethics, 124(2), 283-295.

Byrne, B. M. (2004). Testing for multigroup invariance using AMOS graphics: a road less traveled. Structural Equation Modeling, 11(2), 272-300.

Byrne, B. M., \& Stewart, S. M. (2006). Teacher's corner: The MACS approach to testing for multigroup invariance of a second-order structure: A walk through the process. Structural Equation Modeling, 13(2), 287-321.

Carrington, M. J., Zwick, D., \& Neville, B. A. (2016). The ideology of the ethical consumption gap. Marketing Theory, 16(1), 21-38.

Chiang, C.-Y., Kocabasoglu-Hillmer, C., \& Suresh, N. (2012). An empirical investigation of the impact of strategic sourcing and flexibility on firm's supply chain agility. International Journal of Operations \& Production Management, 32(1), 49-78.

Cho, Y.-N., Thyroff, A., Rapert, M. I., Park, S.-Y., \& Lee, H. J. (2013). To be or not to be green: Exploring individualism and collectivism as antecedents of environmental behavior. Journal of Business Research, 66(8), 1052-1059.

Crano, W. D. (1983). Assumed consensus of attitudes: The effect of vested interest. Personality and Psychology Bulletin, 9(4), 597-607.

Crano, W. D., \& Prislin, R. (1995). Components of vested interest and attitude-behavior consistency. Basic and Applied Social Psychology, 17(1-2), 1-21.

De Dominicis, S., Crano, W. D., Cancellieri, U. G., Mosco, B., Bonnes, M., Hohman, Z., \& Bonaiuto, M. (2014). Vested interest and environmental risk communication: improving willingness to cope with impending disasters. Journal of Applied Social Psychology, 44(5), 364-374.

Dimitrov, D.M. (2010). Testing for factorial invariance in the context of construct validation. Measurement and Evaluation in Counseling and Development, 43(2), 121-149.

Doorn, J. van, \& Verhoef, P. C. (2015). Drivers of and barriers to organic purchase behaviour. Journal of Retailing, 91(3), 436-450.

European Commission. (2012). Policies to encourage sustainable consumption. From: http://ec.europa.eu/environment/eussd/pdf/report_22082012.pdf

Fornell, C., \& Larcker, D.F. (1981). Evaluating structural equation models with unobservable variables and measurement error. Journal of Marketing Research, 18(1), 39-50.

Gleim, M. R., Smith, J. S., Andrews, D., \& Cronin Jr., J. J. (2013). Against the green: A multi-method examination of the barriers to green consumption. Journal of Retailing, 89(1), 44-61.

Goncalves, H. M., Lourenco, T. F., \& Silva, G. M. (2016). Green buying behavior and the theory of consumption values: A fuzzy-set approach. Journal of Business Research, 69(4), 1484-1491. 
Groot, J. I. M. de, \& Steg, L. (2009). Mean or green: Which values can promote stable proenvironmental behavior? Conservation Letters, 2(2), 61-66.

Groot, J. I. M. de, \& Steg, L. (2010). Relationships between value orientations, selfdetermined motivational types and pro-environmental behavioural intentions. Journal of Environmental Psychology, 30(4), 368-378.

Han, H., Hwang, J., \& Lee, M. J. (2017). The value-belief-emotion-norm model: investigating customoers' eco-friendly behavior. Journal of Travel \& Tourism Marketing, 34(5), 590-607.

Hasanzade, V., Osburg, V.-S., \& Toporowski, W. (2018). Selecting decision-relevant ethical product attributes for grocery shopping. Management Decision, 56(3), 591-609.

Jansson, J., Marell, A., \& Nordlund, A. (2010). Green consumer behavior: Determinants of curtailment and eco-innovation adoption. Journal of Consumer Marketing, 27(4), 358370.

Johnson, B. T., \& Eagly, A. H. (1989). Effects of involvement on persuasion: A metaanalysis. Psychological Bulletin, 106(2), 290-314.

Kiatkawsin, K., \& Han, H. (2017). Young travellers' intention to behave proenvironmentally: Merging the value belief-norm theory and expectancy theory. Tourism Management, 59, 76-88.

Kline, R. B. (2011). Principles and practice of structural equation modeling. New York: Guildford press.

Klöckner, C. A. (2013). A comprehensive model of the psychology of environmental behavior - a meta-analysis. Global Environmental Change, 23(5), 1028-1038.

Lin, L.-Y., \& Chen, C.-S. (2006). The influence of the country-of-origin image, product knowledge and product involvement on consumer purchase decisions: an empirical study of insurance and catering services in Taiwan. Journal of Consumer Marketing, 23(5), 248-265.

Luchs, M. G., Naylor, R. W., Irwin, J. R., \& Raghunathan, R. (2010). The sustainability liability: Potential negative effects of ethicality on product preference. Journal of Marketing, 74(5), 18-31.

Marks, G., \& Miller, N. (1987). Ten years of research on the false-consensus effect: An empirical and theoretical overview. Psychological Bulletin, 103(1), 72-90.

McLeay, F., Yoganathan, V., Osburg, V. S., \& Pandit, A. (2018). Risks and drivers of hybrid car adoption: A cross-cultural segmentation analysis. Journal of Cleaner Production, 189, 519-528.

Mitchell, A. A. (1979). Involvement: A potentially important mediator of consumer behavior. Advances in Consumer Research, 6, 191-196.

Mittal, B. (1989). Measuring purchase-decision involvement. Psychology \& Marketing, 6(2), 147-162.

Nordlund, A. M., \& Garvill, J. (2002). Value structures behind proenvironmental behavior. Environment and Behavior, 3(6), 740-756.

Nuttavuthisit, K., \& Thøgersen, J. (2017). The importance of consumer trust for the emergence of a market for green products: The case of organic food. Journal of Business Ethics, 140(2), 323-337. 
Osburg, V.-S., Strack, M., Conroy, D. M., \& Toporowski, W. (2017). Unveiling ethical product features: The importance of an elaborated information presentation. Journal of Cleaner Production, 162, 1582-1591.

Osburg, V.-S., Strack, M., \& Toporowski, W. (2016). Consumer acceptance of WoodPolymer Composites: a conjoint analytical approach with a focus on innovative and environmentally concerned consumers. Journal of Cleaner Production, 110, 180-190.

Osburg, V.-S., Yoganathan, V., Brueckner, S., \& Toporowski, W. (2019). How detailed product information strengthens eco-friendly consumption. Management Decision, https://doi.org/10.1108/MD-10-2017-1012.

Papadas, K.-K., Avlonitis, G. J., \& Carrigan, M. (2017). Green marketing orientation: Conceptualization, scale development and validation. Journal of Business Research, 80, 236-246.

Pelsmacker, P. de, Driesen, L., \& Rayp, G. (2005). Do consumers care about ethics? Willingness to pay for Fair-Trade coffee. The Journal of Consumer Affairs, 39(2), 363385.

Pelsmacker, P. de, \& Janssens, W. (2007). A model for fair trade buying behaviour: The role of perceived quantity and quality of information and product-specific attitudes. Journal of Business Ethics, 75(4), 361-380.

Petty, R. E., \& Cacioppo, J. T. (1986). The Elaboration Likelihood Model of persuasion. In L. Berkowitz (ed.), Advances in experimental social psychology (pp. 123-205). New York: Academic Press.

Preacher, K. J., \& Hayes, A. F. (2008). Asymptotic and resampling strategies for assessing and comparing indirect effects in multiple mediator models. Behavior Research Methods, 40(3), 879-891.

Rokeach, M. (1973). The nature of human values. New York: Free Press.

Schuitema, G., \& Groot, J. I. M. de (2015). Green consumerism: The influence of product attributes and values on purchasing intentions. Journal of Consumer Behaviour, 14(1), 57-69.

Schwartz, S. H. (1992). Universals in the content and structure of values: Theoretical advances and empirical tests in 20 countries. Advances in Experimental Social Psychology, 25, 1-65.

Sekaran, U. (2000). Research methods for business: A skill-building approach. Chichester: John Wiley \& Sons.

Shaw, D., Grehan, E., Shiu, E., Hassan, L., \& Thomson, J. (2005). An exploration of values in ethical consumer decision making. Journal of Consumer Behaviour, 4(3), 185-200.

Soh, H., Reid, L., N., \& King, K. W. (2009). Measuring trust in advertising. Journal of Advertising, 38(2), 83-104.

Steg, L., Dreijerink, L., \& Abrahamse, W. (2005). Factors influencing the acceptability of energy policies: A test of VBN theory. Journal of Environmental Psychology, 25(4), 415-425.

Stern, P. C. (2000). Toward a coherent theory of environmentally significant behavior. Journal of Social Issues, 56(3), 407-424.

Stern, P. C., \& Dietz, T. (1994). The value basis of environmental concern. Social Issues, 50(3), 65-84. 
Stern, P. C., Dietz, T., \& Kalof, L. (1993). Value orientations, gender, and environmental concern. Environment and Behavior, 25(5), 322-348.

Tourangeau, R., Rips, L. J., \& Rasinski, K. (2000). The psychology of survey response. Cambridge: Cambridge University Press.

Urien, B., \& Kilbourne, W. (2011). Generativity and self-enhancement values in eco-friendly behavioral intentions and environmentally responsible consumption behaviour. Psychology \& Marketing, 28(1), 69-90.

Verhoef, P. C., \& Doorn, J. van (2016). Segmenting consumers according to their purchase of products with organic, fair-trade, and health labels. Journal of Marketing Behavior, 2(1), 19-37.

Vermeir, I., \& Verbeke, W. (2006). Sustainable food consumption: Exploring the consumer "attitude - behavioral intention" gap. Journal of Agricultural and Environmental Ethics, 19(2), 169-194.

Vlosky, R. P., Ozanne, L. K., \& Fotenot, R. J. (1999). A conceptual model of US consumer willingness-to-pay for environmentally certified wood products. Journal of Consumer Marketing, 16(2), 122-140.

Ward, D. O., Clark, C. D., Jensen, K. L., Yen, S. T., \& Russell, C. S. (2011). Factors influencing willingness-to-pay for the ENERGY STAR ${ }^{\circledR}$ label. Energy Policy, 39(3), 1450-1458.

Wei, C.-F., Chiang, C. T., Kou, T.-C., \& Lee, B. C. Y. (2017). Toward sustainable livelihoods: Investigating the drivers of purchase behaviour for green products. Business Strategy and the Environment, 26(5), 626-639.

Yoganathan, V., Osburg, V.-S., \& Akhtar, P. (2019). Sensory stimulation for sensible consumption: Multisensory marketing for e-tailing of ethical brands. Journal of Business Research, 96, 386-396.

Zaichkowsky, J. L. (1986). Conceptualizing involvement. Journal of Advertising, 1(2), 4-34. 
Figure 1. Framework conceptualizing the contrasting effects of consumer values on ethical choices depending on consumer receptiveness

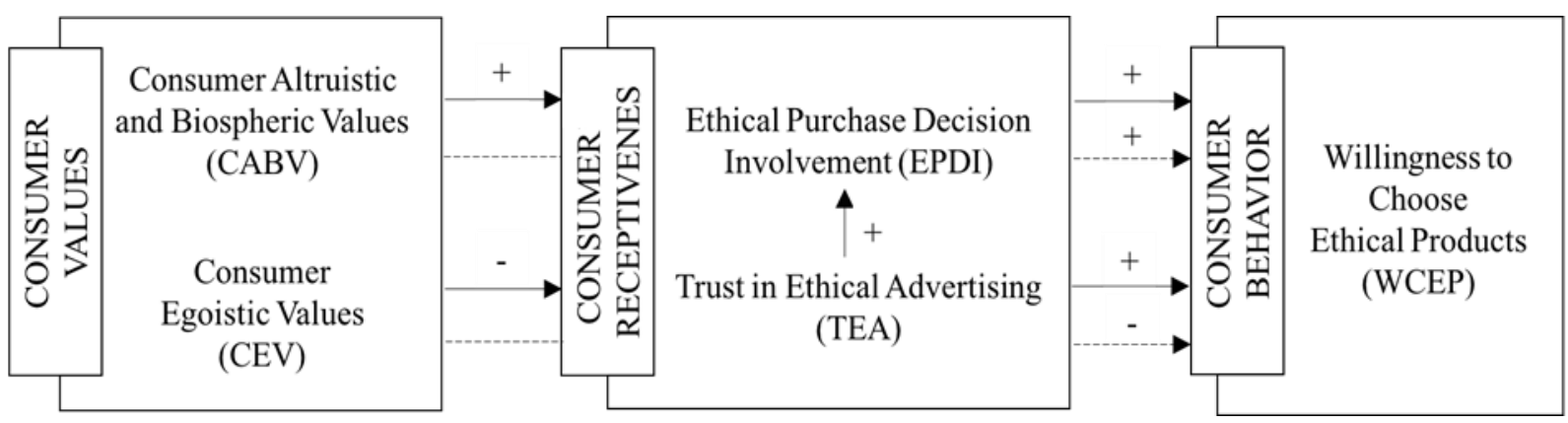

Note: Dotted lines indicate mediations. 
Figure 2a. Consumer altruistic and biospheric values (CABV), individual factors
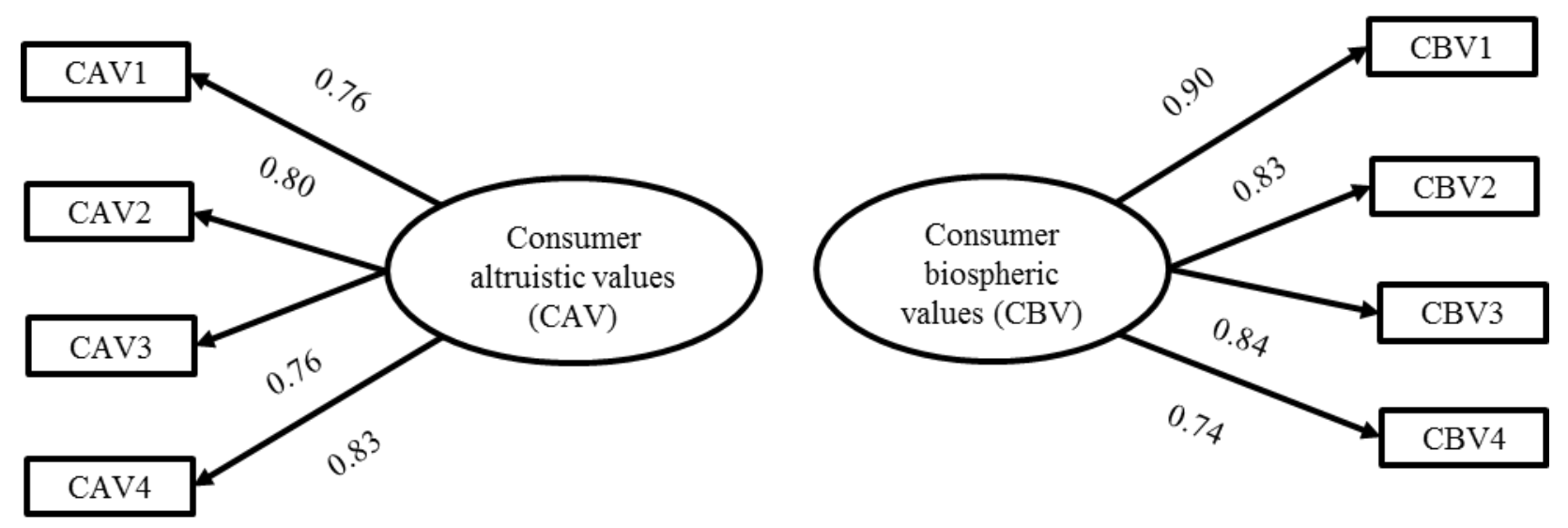

Model fits for consumer altruistic values (CAV)

All loadings are significant at $p<0.01$

$n=590 ; \chi^{2} / \mathrm{df}=2.569(p=0.001) ; \mathrm{GFI}=0.984 ; \mathrm{AGFI}=0.962 ; \mathrm{CFI}=0.993 ; \mathrm{TLI}=0.986 ; \mathrm{IFI}=0.993 ; \mathrm{RFI}=$ $0.978 ; \mathrm{NFI}=0.988 ;$ RMSEA $=0.052$

Model fits for consumer biospheric values (CBV)

All loadings are significant at $p<0.01$

$n=590 ; \chi^{2} / \mathrm{df}=2.777(p=0.096) ; \mathrm{GFI}=0.984 ; \mathrm{AGFI}=0.977 ; \mathrm{CFI}=0.999 ; \mathrm{TLI}=0.993 ; \mathrm{IFI}=0.999 ; \mathrm{RFI}=$ $0.989 ; \mathrm{NFI}=0.998 ;$ RMSEA $=0.055$

Figure $2 b$. Consumer altruistic and biospheric values (CABV), single factor-solution

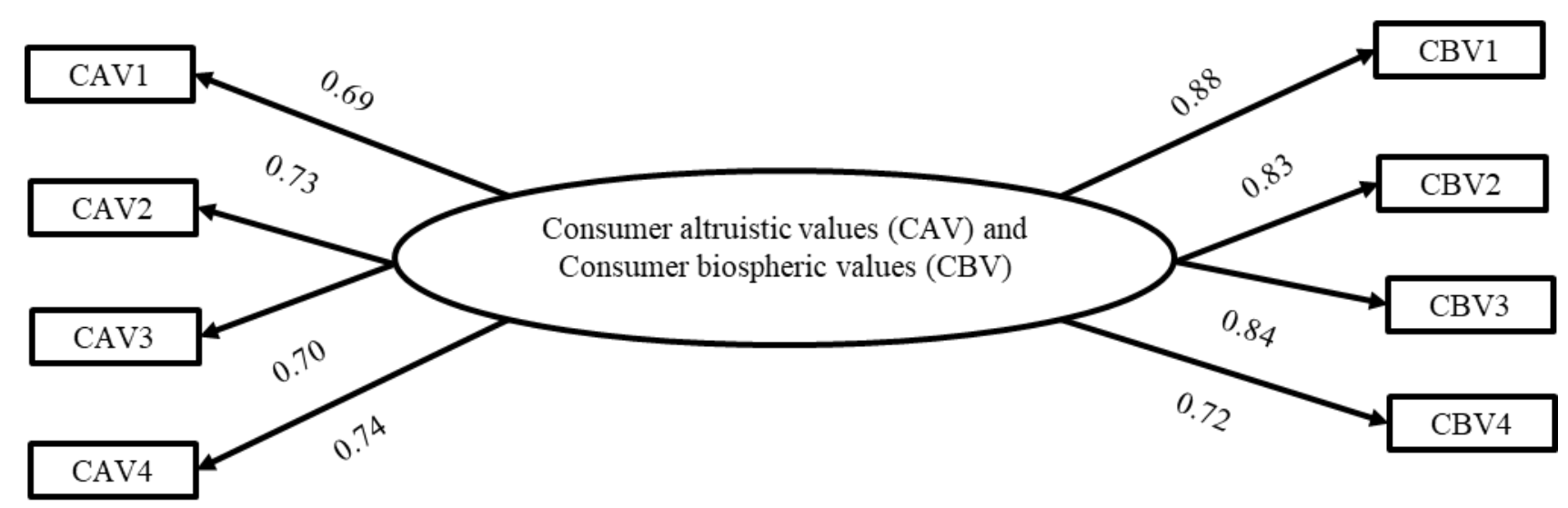

Model fits for a single model testing

All loadings are significant at $p<0.01$

$n=590 ; \chi^{2} / \mathrm{df}=8.776(p=0.001) ; \mathrm{GFI}=0.938 ; \mathrm{AGFI}=0.868 ; \mathrm{CFI}=0.959 ; \mathrm{TLI}=0.932 ; \mathrm{IFI}=0.959 ; \mathrm{RFI}=$

$0.924 ; \mathrm{NFI}=0.954 ;$ RMSEA $=0.115$ 
Figure 2c. Consumer altruistic and biospheric values (CABV), two-factor solution and combined

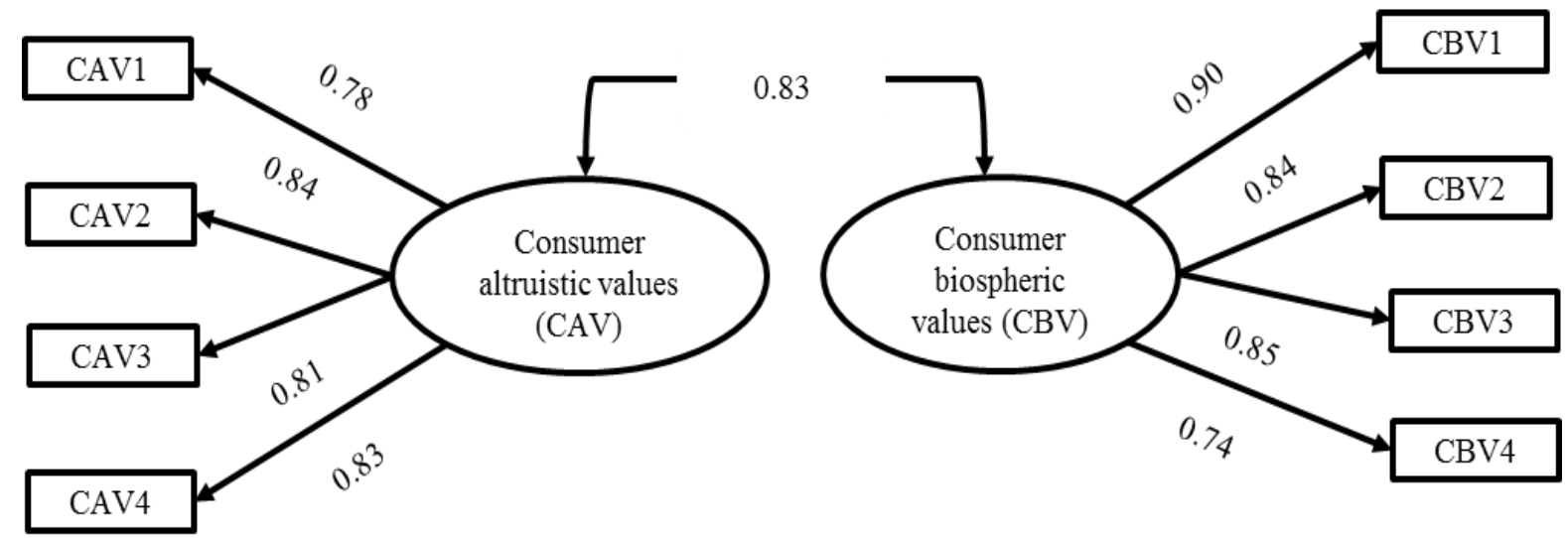

Model fits for combined model testing

All loadings are significant at $p<0.01$

$n=590 ; \chi^{2} / \mathrm{df}=2.569(p=0.001) ; \mathrm{GFI}=0.984 ;$ AGFI $=0.962 ; \mathrm{CFI}=0.993 ; \mathrm{TLI}=0.986 ; \mathrm{IFI}=0.993 ; \mathrm{RFI}=$ $0.978 ; \mathrm{NFI}=0.988 ;$ RMSEA $=0.052$ 
Figure 3. SEM Results for the Interrelationships and Hypothesis Testing

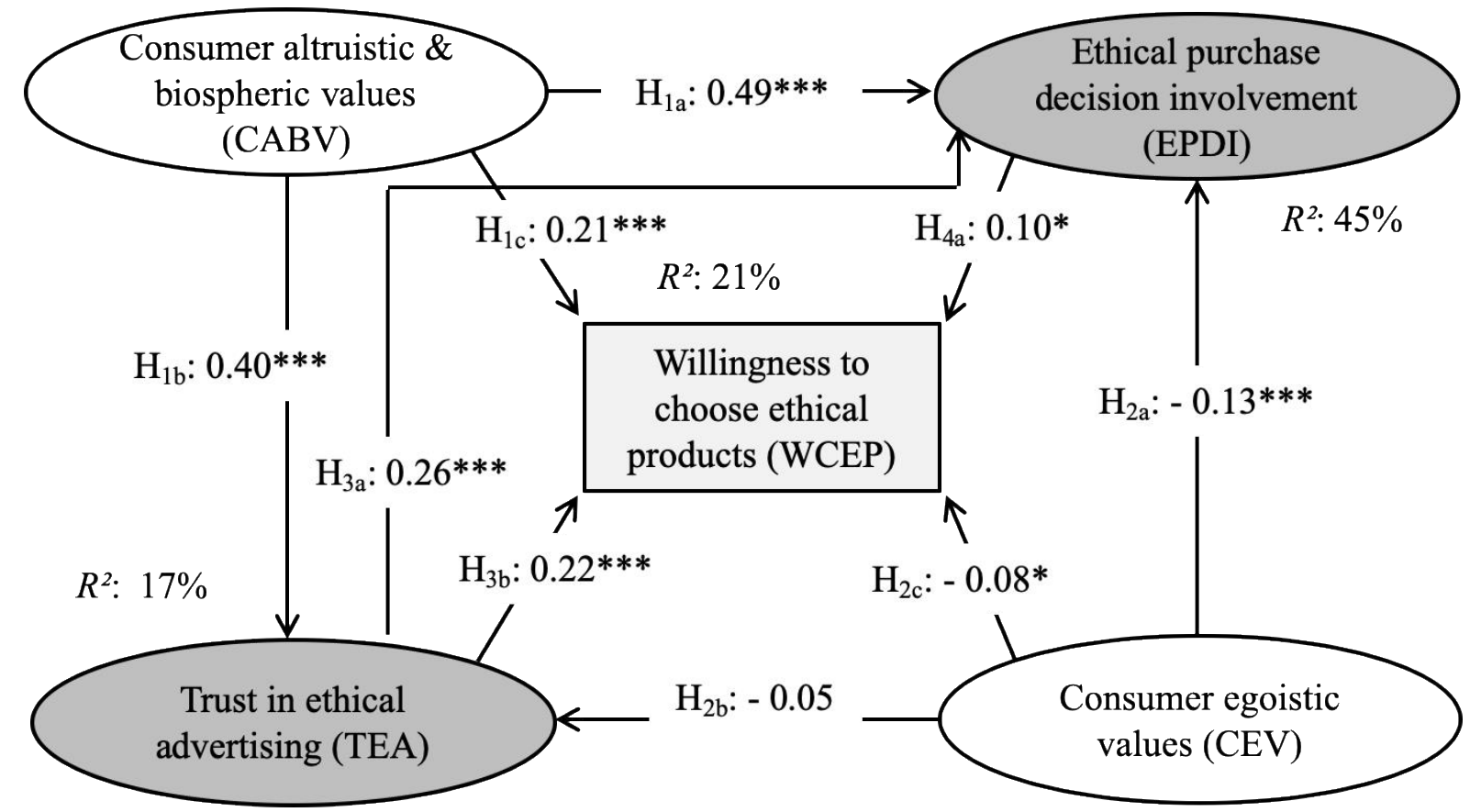

*** (*) statistically significant at $p<0.01(0.1)$

$n=590 ; \chi^{2} / \mathrm{df}=1.068(p=0.268) ; \mathrm{GFI}=0.973 ; \mathrm{AGFI}=0.964 ; \mathrm{CFI}=0.999 ; \mathrm{TLI}=0.999 ; \mathrm{IFI}=0.978 ; \mathrm{RFI}=$ $0.978 ; \mathrm{NFI}=0.982 ; \mathrm{RMSEA}=0.011$ 
Figure 4. Mediating Results (Preacher and Hayes, 2008) and Relative Hypothesis Testing

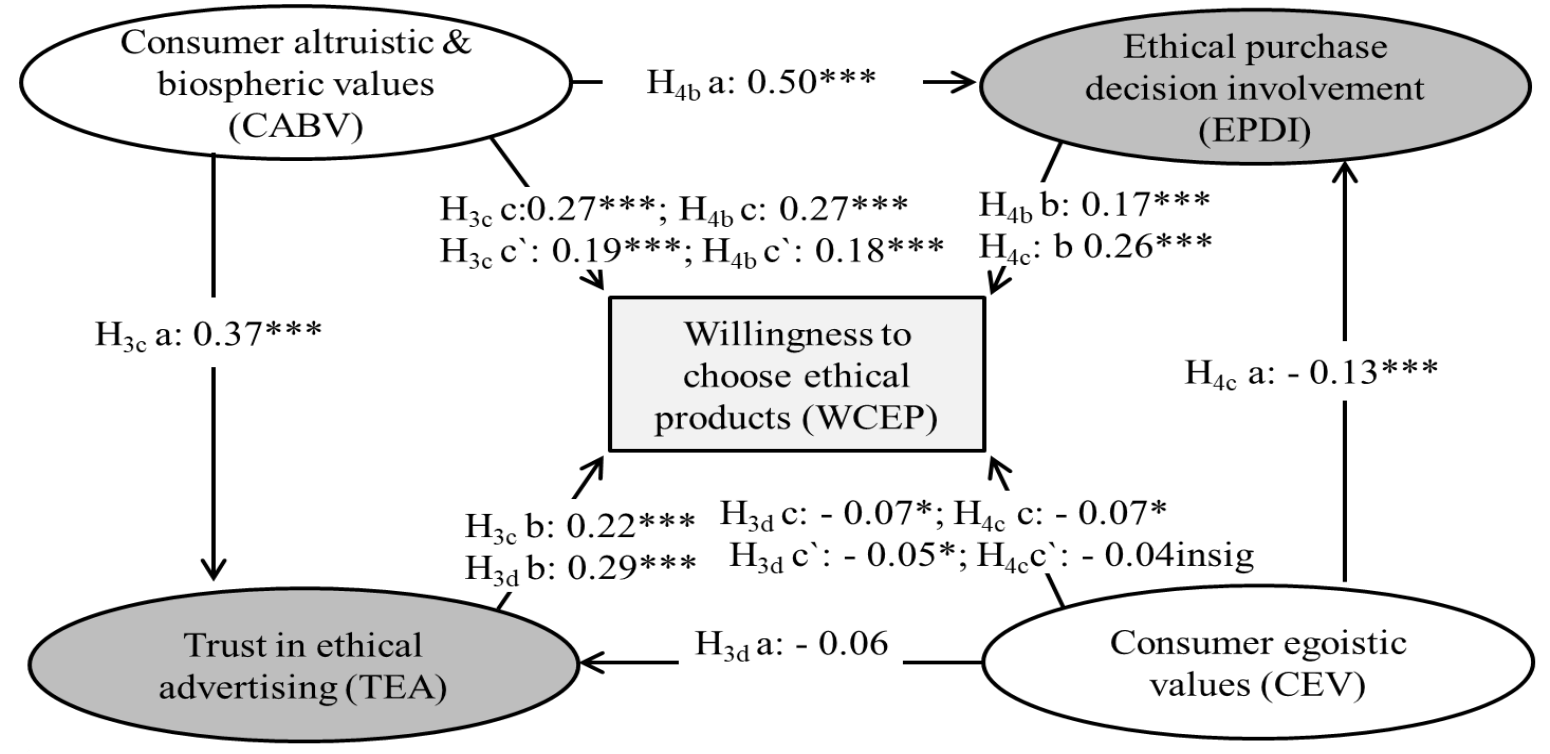

$\mathrm{H}_{3 \mathrm{c}}$ : TEA (shaded) mediates the relationship between CABV and WCEP (partially mediates) $\mathrm{H}_{3 \mathrm{~d}}$ : TEA (shaded) mediates the relationship between CEV and WCEP (partially mediates) $\mathrm{H}_{4 \mathrm{~b}}$ : EPDI (shaded) mediates the relationship between CABV and WCEP (partially mediates) $\mathrm{H}_{4 \mathrm{c}}$ : EPDI (shaded) mediates the relationship between CEV and WCEP (fully mediates) 
Table 1. Overview of selected publications on the influence of value orientations on ethical consumption.

\begin{tabular}{|c|c|c|c|c|}
\hline Authors & $\begin{array}{l}\text { Considered Value } \\
\text { Orientations }\end{array}$ & $\begin{array}{l}\text { Dependent } \\
\text { Variable }\end{array}$ & Method & Core Finding(s) related to Value Orientations \\
\hline $\begin{array}{l}\text { Nordlund } \\
\text { and Garvill } \\
(2002)\end{array}$ & $\begin{array}{l}\text { Self-transcendence, } \\
\text { self-enhancement }{ }^{1}\end{array}$ & $\begin{array}{l}\text { Pro- } \\
\text { environmental } \\
\text { behavior }\end{array}$ & $\begin{array}{l}\text { Survey; } \mathrm{N}=1.429 \\
\text { Swedish residents }\end{array}$ & $\begin{array}{l}\text { a) self-transcendence increases ecocentrism, problem awareness, and personal norm; b) self- } \\
\text { enhancement decreases ecocentrism and problem awareness, and increases anthropocentrism; c) } \\
\text { problem awareness positively affects personal norm, which then strengthens pro-environmental } \\
\text { behavior }\end{array}$ \\
\hline $\begin{array}{l}\text { Pelsmacker } \\
\text { et al. (2005) }\end{array}$ & $\begin{array}{l}\text { Rokeach's (1973) } \\
\text { value orientations }\end{array}$ & $\begin{array}{l}\text { Willingness to } \\
\text { pay (WTP) for } \\
\text { fair trade coffee }\end{array}$ & $\begin{array}{l}\text { Survey; } \mathrm{N}=834 \\
\text { members of staff } \\
\text { of a Dutch } \\
\text { university }\end{array}$ & $\begin{array}{l}\text { a) identification of four segments based on their WTP for fair trade coffee (fair-trade lovers, fair- } \\
\text { trade likers, flavor lovers, brand lovers); b) segments do not differ with respect to the values of } \\
\text { competence as well as sincere and social; c) segments with high WTP for fair-trade coffee show } \\
\text { lower (higher) levels of conventionalism and personal gratification (idealism) }\end{array}$ \\
\hline $\begin{array}{l}\text { Steg et al. } \\
(2005)\end{array}$ & $\begin{array}{l}\text { Altruistic, } \\
\text { biospheric, and } \\
\text { egoistic values }\end{array}$ & $\begin{array}{l}\text { Acceptability of } \\
\text { energy policies to } \\
\text { reduce } \mathrm{CO}_{2} \\
\text { emissions }\end{array}$ & $\begin{array}{l}\text { Survey; } N=112 \\
\text { Dutch residents }\end{array}$ & $\begin{array}{l}\text { a) biospheric values are positively related to the New Environmental Paradigm (NEP); b) egoistic } \\
\text { values are negatively related to NEP; c) altruistic values do not significantly contribute to NEP; } \\
\text { d) further results support assumptions of VBN theory (Stern, 2000) (i.e., mediated relationships } \\
\text { from values via beliefs (e.g., NEP) and personal norm to behavior) }\end{array}$ \\
\hline $\begin{array}{l}\text { Groot and } \\
\text { Steg (2009) }\end{array}$ & $\begin{array}{l}\text { Altruistic, } \\
\text { biospheric, and } \\
\text { egoistic values }\end{array}$ & $\begin{array}{l}\text { Pro- } \\
\text { environmental } \\
\text { behavior }\end{array}$ & Conceptual paper & $\begin{array}{l}\text { a) altruistic and biospheric values as most stable predictors of pro-environmental behavior, i.e., } \\
\text { salience of altruistic and biospheric features should be enhanced; b) egoistic values may } \\
\text { positively affect pro-environmental behavior under certain conditions (personal benefits outweigh } \\
\text { personal costs); i.e., individual benefits should be highlighted }\end{array}$ \\
\hline $\begin{array}{l}\text { Groot and } \\
\text { Steg }(2010)\end{array}$ & $\begin{array}{l}\text { Altruistic, } \\
\text { biospheric, and } \\
\text { egoistic values }\end{array}$ & $\begin{array}{l}\text { Donation } \\
\text { intention, } \\
\text { intention to buy } \\
\text { eco-friendly car }\end{array}$ & $\begin{array}{l}\text { Survey; } n=520 \\
\text { and } n=304 \text { Dutch } \\
\text { students }\end{array}$ & $\begin{array}{l}\text { a) altruistic and biospheric values (egoistic values) increase (decrease) self-determination to } \\
\text { donate/choose an eco-friendly car; b) egoistic values are positively related to amotivation and } \\
\text { external regulation }\end{array}$ \\
\hline $\begin{array}{l}\text { Urien and } \\
\text { Kilbourne } \\
(2011)\end{array}$ & Self-enhancement $^{1}$ & $\begin{array}{l}\text { Eco-friendly } \\
\text { behavioral } \\
\text { intentions }\end{array}$ & $\begin{array}{l}\text { Survey; } \mathrm{n}=283 \\
\text { US and } \mathrm{n}=198 \\
\text { French students }\end{array}$ & $\begin{array}{l}\text { a) self-enhancement does not directly influence eco-friendly behavioral intentions; b) self- } \\
\text { enhancement interacts with generativity (i.e., belief that behavior has implications for future } \\
\text { generations) in that high self-enhancement paired with i) low generativity reduces the intention to } \\
\text { behave in an eco-friendly way, ii) high generativity still leads to eco-friendly behavioral } \\
\text { intentions }\end{array}$ \\
\hline $\begin{array}{l}\text { Klöckner } \\
(2013)\end{array}$ & $\begin{array}{l}\text { Self-transcendence, } \\
\text { self-enhancement }{ }^{1}\end{array}$ & $\begin{array}{l}\text { Environmental } \\
\text { behavior }\end{array}$ & $\begin{array}{l}\text { Meta-analysis ( } 56 \\
\text { data sets) about } \\
\text { the psychology of } \\
\text { environmental } \\
\text { behavior }\end{array}$ & $\begin{array}{l}\text { a) self-transcendence positively influences NEP; b) self-enhancement negatively affects NEP; c) } \\
\text { the causal chains as specified by VBN cannot be confirmed; d) value orientation has an indirect } \\
\text { effect on environmental behavior }\end{array}$ \\
\hline
\end{tabular}




\begin{tabular}{|c|c|c|c|c|}
\hline $\begin{array}{l}\text { Doorn and } \\
\text { Verhoef } \\
\text { (2015) }\end{array}$ & $\begin{array}{l}\text { Altruistic, } \\
\text { biospheric, and } \\
\text { egoistic values }\end{array}$ & $\begin{array}{l}\text { Purchases of } \\
\text { organic products }\end{array}$ & $\begin{array}{l}\text { i) household } \\
\text { behavioral data, } \\
\text { ii) supply-side } \\
\text { data; iii) } \\
\text { household survey } \\
\text { (N=1.246) }\end{array}$ & $\begin{array}{l}\text { a) biospheric values increase a household's share of organic purchases; b) high biospheric values } \\
\text { result in reduced price sensitivity and higher likelihood of purchasing organic products given low } \\
\text { availability of such products; c) altruistic values do not seem to significantly affect organic } \\
\text { purchases; d) egoistic values negatively affect organic purchases }\end{array}$ \\
\hline $\begin{array}{l}\text { Schuitema } \\
\text { and Groot } \\
(2015)\end{array}$ & $\begin{array}{l}\text { Biospheric, and } \\
\text { egoistic values }\end{array}$ & $\begin{array}{l}\text { Purchase } \\
\text { intention }\end{array}$ & $\begin{array}{l}\text { Survey }(\mathrm{n}=100, \\
\text { convenience } \\
\text { sample) and } \\
\text { experiment; (n107 } \\
\text { UK residents) }\end{array}$ & $\begin{array}{l}\text { a) biospheric values increase preference for selected environmental product attributes; b) egoistic } \\
\text { values do not affect preference for environmental product attributes, but interact with brand } \\
\text { equity (i.e., stronger preference for well-known brands) }\end{array}$ \\
\hline $\begin{array}{l}\text { Verhoef and } \\
\text { Doorn } \\
(2016)\end{array}$ & $\begin{array}{l}\text { Altruistic, } \\
\text { biospheric, and } \\
\text { egoistic values }\end{array}$ & $\begin{array}{l}\text { Share of wallet } \\
\text { per label (health } \\
\text { labels and } \\
\text { sustainable (i.e., } \\
\text { organic and fair- } \\
\text { trade) labels) }\end{array}$ & $\begin{array}{l}\text { Two periods of } \\
\text { household panel } \\
\text { data collection }\end{array}$ & $\begin{array}{l}\text { a) identification of four segments related to their purchasing behavior (conventional products, } \\
\text { health label, sustainable and health label, sustainable label); b) segments of conventional product } \\
\text { and health label buyers show lower biospheric values, whereas segments of sustainable as well as } \\
\text { sustainable and health label buyers show stronger biospheric values; c) egoistic values do not } \\
\text { significantly predict segment membership }\end{array}$ \\
\hline $\begin{array}{l}\text { Han et al. } \\
(2017)\end{array}$ & $\begin{array}{l}\text { Altruistic, } \\
\text { biospheric, and } \\
\text { egoistic values }\end{array}$ & $\begin{array}{l}\text { Purchase } \\
\text { intention, Word- } \\
\text { of-Mouth } \\
\text { intention, } \\
\text { Willingness to } \\
\text { sacrifice }\end{array}$ & $\begin{array}{l}\text { Survey; } \mathrm{N}=350 \\
\text { US cruise } \\
\text { customers }\end{array}$ & $\begin{array}{l}\text { a) altruistic and biospheric values positively affect a customer's ecological worldview (as } \\
\text { specified in VBN theory), which then affects the dependent variables through a causal chain; b) } \\
\text { egoistic values do not show any significant influence }\end{array}$ \\
\hline $\begin{array}{l}\text { Kiatkawsin } \\
\text { and Han } \\
\text { (2017) }\end{array}$ & $\begin{array}{l}\text { Altruistic, } \\
\text { biospheric, and } \\
\text { egoistic values }\end{array}$ & $\begin{array}{l}\text { Intention to } \\
\text { behave pro- } \\
\text { environmentally } \\
\text { while travelling }\end{array}$ & $\begin{array}{l}\text { Survey; } \mathrm{N}=552 \\
\text { South Korean } \\
\text { students }\end{array}$ & $\begin{array}{l}\text { a) altruistic and biospheric values positively affect the NEP, which then affects the behavioral } \\
\text { intention through a causal chain specified by VBN and expectancy theory (indirect impact of both } \\
\text { values confirmed); b) egoistic values do not show a direct or indirect influence }\end{array}$ \\
\hline $\begin{array}{l}\text { Yoganathan } \\
\text { et al. (2019) }\end{array}$ & $\begin{array}{l}\text { Altruistic and } \\
\text { biospheric values }\end{array}$ & $\begin{array}{l}\text { Willingness to } \\
\text { Pay (WTP) for an } \\
\text { ethical (fair trade } \\
\text { and organic) soft } \\
\text { toy }\end{array}$ & $\begin{array}{l}\text { Online } \\
\text { experiment; } \\
\mathrm{N}=308 \text { US online } \\
\text { shoppers }\end{array}$ & $\begin{array}{l}\text { a) ethically-related multisensory cues increase WTP for ethical products online; b) when ethical } \\
\text { multisensory cues are provided, consumers with average/high altruistic and biospheric value } \\
\text { orientations form stronger ethical brand perceptions (i.e., stronger mediation of perceived brand } \\
\text { ethicality between multisensory cues and WTP) }\end{array}$ \\
\hline
\end{tabular}

${ }^{1}$ Self-transcendence represents altruistic and self-enhancement egoistic value orientations (see: Groot and Steg, 2009). 
Table 2. Sample characterization.

\begin{tabular}{|c|c|c|}
\hline Socio-demographic characteristic & $\mathrm{n}$ & $\%$ \\
\hline \multicolumn{3}{|l|}{ Highest Education } \\
\hline None & 2 & .3 \\
\hline High-school diploma & 115 & 19.5 \\
\hline Some college & 257 & 43.6 \\
\hline Bachelor's degree & 157 & 26.6 \\
\hline Master's degree & 56 & 9.5 \\
\hline Terminal degree & 3 & .5 \\
\hline \multicolumn{3}{|l|}{ Household Size } \\
\hline 1 & 118 & 20.0 \\
\hline 2 & 182 & 30.8 \\
\hline 3 & 112 & 19.0 \\
\hline 4 & 98 & 16.6 \\
\hline $5-6$ & 66 & 11.2 \\
\hline 7 and more & 14 & 2.4 \\
\hline \multicolumn{3}{|l|}{ Household income (year) } \\
\hline Less than 25.000 USD & 183 & 31.0 \\
\hline $25.001-50.000 \mathrm{USD}$ & 209 & 35.4 \\
\hline $50.001-100.000$ USD & 157 & 26.6 \\
\hline $100.001-150.000$ USD & 31 & 5.3 \\
\hline More than 150.000 USD & 10 & 1.7 \\
\hline
\end{tabular}


Table 3. Descriptive Statistics

\begin{tabular}{lccccccc}
\hline Constructs & $\bar{x}$ & $\sigma$ & CABV & TEA & EPDI & CEV & WCEP \\
\hline $\begin{array}{l}\text { Consumer altruistic \& } \\
\text { biospheric values (CABV) }\end{array}$ & 6.30 & 1.27 & 1 & & & & \\
$\begin{array}{l}\text { Trust in ethical advertising } \\
\text { (TEA) }\end{array}$ & 4.28 & 1.21 & 0.40 & 1 & & & \\
$\begin{array}{l}\text { Ethical purchase decision } \\
\text { involvement (EPDI) }\end{array}$ & 4.74 & 1.20 & 0.54 & 0.47 & 1 & & \\
$\begin{array}{l}\text { Consumer egoistic values } \\
\text { (CEV) }\end{array}$ & 3.91 & 1.79 & $-0.10^{* *}$ & $-0.01^{* *}$ & 0.20 & 1 & \\
$\begin{array}{l}\text { Willingness to choose ethical } \\
\text { products (WCEP) }\end{array}$ & N/A & N/A & 0.35 & 0.36 & 0.33 & $-0.13^{* *}$ & 1 \\
\hline
\end{tabular}

$\bar{x}$ (mean); $\sigma$ (standard deviation); $\mathrm{n}=590$; all correlations are significant at $p<0.01$ and $p<$ $0.05\left({ }^{* *}\right)$ 
Table 4. Reliability and Validity of Constructs, Evaluation of Measurement Model

\begin{tabular}{|c|c|c|c|c|c|}
\hline \multirow{2}{*}{$\begin{array}{l}\text { Constructs } \\
\text { Consumer altruistic \& } \\
\text { biospheric values (CABV): }\end{array}$} & Items & $\alpha$ & $\lambda(\mathrm{C} . \mathrm{R})$ & AVE & C.R \\
\hline & $\begin{array}{l}\text { CABV1 } \\
\text { CABV2 } \\
\text { CABV3 } \\
\text { CABV4 } \\
\text { CABV5 } \\
\text { CABV6 } \\
\text { CABV7 } \\
\text { CABV8 }\end{array}$ & 0.91 & $\begin{array}{c}- \\
0.72 \text { (fixed) } \\
0.65(17.553) \\
0.71(17.698) \\
0.89(20.162) \\
0.84(19.151) \\
0.86(18.229) \\
-\end{array}$ & 0.61 & 0.90 \\
\hline $\begin{array}{l}\text { Trust in ethical advertising } \\
\text { (TEA): }\end{array}$ & $\begin{array}{l}\text { TEA1 } \\
\text { TEA2 } \\
\text { TEA3 } \\
\text { TEA4 } \\
\text { TEA5 } \\
\text { TEA6 }\end{array}$ & 0.96 & $\begin{array}{c}0.92 \text { (fixed) } \\
0.93(38.595) \\
0.91(41.705) \\
0.93(39.490) \\
0.96(37.315) \\
0.86(32.842)\end{array}$ & 0.84 & 0.97 \\
\hline $\begin{array}{l}\text { Ethical purchase decision } \\
\text { involvement (EPDI): }\end{array}$ & $\begin{array}{l}\text { EPDI1 } \\
\text { EPDI2 }^{a} \\
\text { EPDI3 } \\
\text { EPDI4 }\end{array}$ & 0.85 & $\begin{array}{l}0.72 \text { (fixed) } \\
0.88(19.260) \\
0.85(18.229)\end{array}$ & 0.67 & 0.86 \\
\hline $\begin{array}{l}\text { Consumer egoistic values } \\
\text { (CEV): }\end{array}$ & $\begin{array}{l}\text { CEV1 } \\
\text { CEV2 } \\
\text { CEV3 } \\
\text { CEV4 }\end{array}$ & 0.89 & $\begin{array}{l}0.89 \text { (fixed) } \\
0.76(20.318) \\
0.82(24.705) \\
0.79(21.293)\end{array}$ & 0.67 & 0.89 \\
\hline
\end{tabular}

aItem was deleted because of high modification indices (CVs1 and CVs8)/low loadings (EPDI2); $\alpha=$ items reliability; $\lambda=$ loadings; $C . R=$ critical rations: $A V E=$ average variance extracted; $C . R$ $=$ construct reliability; all loadings are significant at $\mathrm{p}<0.01$ 
Table 5. Second method for discriminant validity

\begin{tabular}{llll|l}
\hline & Statistics & & & Condition met \\
\hline Constructs & $\phi$ & $\phi^{2}$ & AVE & $\phi^{2}<$ AVE \\
\hline CABV \& TEA & 0.40 & $0.16 \mathrm{a}$ & $0.73 \mathrm{~b}$ & Yes \\
CABV \& EPDI & 0.54 & 0.29 & 0.64 & Yes \\
CABV \& CEV & -0.10 & 0.01 & 0.64 & Yes \\
TEA \& EPDI & 0.47 & 0.22 & 0.76 & Yes \\
TEA \& CEV & -0.01 & 0.00 & 0.76 & Yes \\
EPDI \& CEV & 0.20 & 0.04 & 0.67 & Yes \\
\hline
\end{tabular}

$\phi=$ correlation between factors, a $\phi 2,0.36^{*} 0.36=0.13$; bAVE, $(0.61+0.84) / 2=0.56$ (AVE for CABV \& TEA) 
Table 6. Construct Codes and Cross-Loadings, EFA Results showing Validity of Constructs

\begin{tabular}{lrrrr}
\hline Construct codes (and content) & CABV & \multicolumn{1}{l}{ TEA } & CEV & EPDI \\
\hline CABV1 (Social justice) & $\mathbf{0 . 7 8 5}$ & 0.108 & 0.087 & -0.050 \\
CABV2 (Helpful) & $\mathbf{0 . 7 6 8}$ & 0.165 & 0.107 & -0.053 \\
CABV3 (Equality) & $\mathbf{0 . 8 0 1}$ & 0.064 & 0.047 & -0.081 \\
CABV4 (A world at peace) & $\mathbf{0 . 7 8 9}$ & 0.162 & 0.082 & -0.043 \\
CABV5 (Environment protection) & $\mathbf{0 . 8 0 3}$ & 0.166 & 0.266 & -0.028 \\
CABV6 (Preventing pollution) & $\mathbf{0 . 7 6 4}$ & 0.184 & 0.262 & 0.029 \\
CABV7 (Respecting the earth) & $\mathbf{0 . 7 9 6}$ & 0.130 & 0.270 & 0.027 \\
CABV8 (Unity with nature) & $\mathbf{0 . 6 6 7}$ & 0.210 & 0.319 & -0.027 \\
TEA1 (Honest) & 0.162 & $\mathbf{0 . 9 1 3}$ & 0.141 & -0.003 \\
TEA2 (Truthful) & 0.162 & $\mathbf{0 . 9 1 5}$ & 0.163 & -0.024 \\
TEA3 (Credible) & 0.173 & $\mathbf{0 . 8 9 5}$ & 0.186 & -0.029 \\
TEA4 (Reliable) & 0.165 & $\mathbf{0 . 9 0 3}$ & 0.180 & -0.016 \\
TEA5 (Accurate) & 0.175 & $\mathbf{0 . 8 7 6}$ & 0.199 & -0.028 \\
TEA6 (Factual) & 0.199 & $\mathbf{0 . 8 5 9}$ & 0.148 & -0.075 \\
EPDI1 (Careful choices) & 0.290 & 0.165 & $\mathbf{0 . 7 4 0}$ & -0.071 \\
EPDI2 (Similarity of alternatives) & 0.081 & 0.272 & $\mathbf{0 . 6 2 6}$ & -0.120 \\
EPDI3 (Choice importance) & 0.322 & 0.203 & $\mathbf{0 . 7 8 2}$ & -0.098 \\
EPDI4 (Choice outcome) & 0.290 & 0.198 & $\mathbf{0 . 7 8 5}$ & -0.045 \\
CEV1 (Authority) & -0.083 & -0.045 & -0.087 & $\mathbf{0 . 8 9 4}$ \\
CEV2 (Social power) & -0.032 & -0.035 & -0.054 & $\mathbf{0 . 8 3 3}$ \\
CEV3 (Wealth) & 0.004 & -0.036 & -0.075 & $\mathbf{0 . 8 6 6}$ \\
CEV4 (Influential) & -0.042 & -0.004 & -0.056 & $\mathbf{0 . 8 4 9}$ \\
\hline & & & &
\end{tabular}


Table 7. Alternative Models and Moderation by Products (Multi-Group Analysis)

\begin{tabular}{|c|c|c|c|c|c|c|}
\hline \multirow[t]{2}{*}{ Variables } & \multicolumn{2}{|l|}{ Model 1} & \multicolumn{2}{|l|}{ Model 2} & \multicolumn{2}{|l|}{ Model 3} \\
\hline & $\beta$ & C.R & $\beta$ & C.R & $\beta$ & C.R \\
\hline \multicolumn{7}{|c|}{ Independent variables (without inter-relationships between them) } \\
\hline $\begin{array}{l}\text { Consumer altruistic \& } \\
\text { biospheric values } \\
(\mathrm{CABV})\end{array}$ & $0.22 * * *$ & 5.351 & & & & \\
\hline $\begin{array}{l}\text { Ethical purchase } \\
\text { decision involvement } \\
\text { (EPDI) }\end{array}$ & $0.12 * * *$ & 2.911 & & & & \\
\hline $\begin{array}{l}\text { Trust in ethical } \\
\text { advertising (TEA) }\end{array}$ & $0.24 * * *$ & 6.069 & & & & \\
\hline $\begin{array}{l}\text { Consumer egoistic } \\
\text { values }(\mathrm{CEV})\end{array}$ & $-0.08 * *$ & -2.004 & & & & \\
\hline \multicolumn{7}{|c|}{$\begin{array}{l}\text { Inter-relationships of independent variables, their direct relationships and moderations by } \\
\text { products (chocolate and chairs) }\end{array}$} \\
\hline $\mathrm{CABV} \rightarrow \mathrm{EPDI}$ & & & $0.54 * * *$ & 7.967 & $0.44 * * *$ & 6.141 \\
\hline $\mathrm{CABV} \rightarrow \mathrm{TEA}$ & & & $0.37 * * *$ & 5.790 & $0.44 * * *$ & 7.060 \\
\hline $\mathrm{CABV} \rightarrow \mathrm{WCEP}$ & & & $0.18 * *$ & 2.241 & $0.23 * * *$ & 3.194 \\
\hline $\mathrm{TEA} \rightarrow \mathrm{EPDI}$ & & & $0.30 * * *$ & 5.356 & $0.22 * * *$ & 3.677 \\
\hline TEA $\rightarrow$ WCEP & & & $0.21 * * *$ & 3.235 & $0.21 * * *$ & 3.495 \\
\hline $\mathrm{EPDI} \rightarrow \mathrm{WCEP}$ & & & 0.13 & 1.518 & 0.11 & 1.497 \\
\hline $\mathrm{CEV} \rightarrow \mathrm{EPDI}$ & & & -0.07 & -1.465 & $-0.20 * * *$ & -3.528 \\
\hline $\mathrm{CEV} \rightarrow \mathrm{TEA}$ & & & -0.09 & -1.549 & -0.01 & -0.114 \\
\hline $\mathrm{CEV} \rightarrow \mathrm{WCEP}$ & & & $-0.10^{*}$ & -1.799 & -0.06 & -1.005 \\
\hline \multirow[t]{3}{*}{$R^{2}$} & \multirow{3}{*}{\multicolumn{2}{|c|}{0.13 (WCEP) }} & \multirow{3}{*}{\multicolumn{2}{|c|}{$\begin{array}{l}0.15 \text { (TEA) } \\
0.20(\text { WCEP) } \\
0.51(\text { EPDI) }\end{array}$}} & \multirow{3}{*}{\multicolumn{2}{|c|}{$\begin{array}{l}0.19 \text { (TEA) } \\
0.21 \text { (WCEP) } \\
0.40 \text { (EPDI) }\end{array}$}} \\
\hline & & & & & & \\
\hline & & & & & & \\
\hline$\chi^{2 / \mathrm{df}}$ & \multicolumn{2}{|l|}{3.374} & \multicolumn{4}{|c|}{1.151} \\
\hline$p$-values & \multicolumn{2}{|l|}{0.000} & \multicolumn{4}{|c|}{0.035} \\
\hline GFI & \multicolumn{2}{|l|}{0.914} & \multicolumn{4}{|c|}{0.944} \\
\hline AGFI & \multicolumn{2}{|l|}{0.887} & \multicolumn{4}{|c|}{0.924} \\
\hline CFI & \multicolumn{2}{|l|}{0.959} & \multicolumn{4}{|c|}{0.995} \\
\hline TLI & \multicolumn{2}{|l|}{0.951} & \multicolumn{4}{|c|}{0.994} \\
\hline IFI & \multicolumn{2}{|l|}{0.959} & \multicolumn{4}{|c|}{0.995} \\
\hline RFI & \multicolumn{2}{|l|}{0.932} & \multicolumn{4}{|c|}{0.955} \\
\hline NFI & \multicolumn{2}{|l|}{0.943} & \multicolumn{4}{|c|}{0.964} \\
\hline RMSEA & \multicolumn{2}{|l|}{0.063} & \multicolumn{4}{|c|}{0.016} \\
\hline
\end{tabular}

Key: $* * *(* *, *)$ statistically significant at $p<0.01(0.05,0.1)$; Willingness to choose ethical products (WCEP); critical rations (C.R); Model 2 moderated by chocolate ( $\mathrm{n}=281$ ); Model 3 moderated by chairs $(n=309)$ 
Table 8. Mediating Results, Direct and Indirect Effects

\begin{tabular}{lllll}
\hline Effects & $\beta$ & T-values & Significance & Mediation types \\
\hline $\mathrm{CAB} \rightarrow$ TEA $\rightarrow$ WCEP & & & & Partial \\
Indirect (a) & 0.37 & 10.402 & Yes & \\
Direct (c) & 0.27 & 8.985 & Yes & Partial \\
$\mathrm{CEV} \rightarrow$ TEA $\rightarrow$ WCEP & & & & \\
Indirect (a) & -0.06 & -2.188 & Yes & \\
Direct (c) & -0.07 & 3.255 & Yes & Partial \\
CABV $\rightarrow$ EPDI $\rightarrow$ WCEP & & & & \\
Indirect (a) & 0.50 & 15.430 & Yes & Full \\
Direct (c) & 0.27 & 8.985 & Yes & \\
CEV $\rightarrow$ EPDI $\rightarrow$ WCEP & & & & \\
Indirect (a) & -0.13 & -4.188 & Yes & \\
Direct (c) & -0.07 & -3.255 & Yes & \\
\hline
\end{tabular}

